Louisiana State University

LSU Digital Commons

Faculty Publications

Department of Chemistry

$4-22-2014$

\title{
Synthesis and transformations of 5-chloro-2,2'-dipyrrins and their boron complexes, 8-chloro-BODIPYs
}

\author{
Haijun Wang \\ Louisiana State University \\ M. Graça H. Vicente \\ Louisiana State University \\ Frank R. Fronczek \\ Louisiana State University \\ Kevin M. Smith \\ Louisiana State University
}

Follow this and additional works at: https://digitalcommons.Isu.edu/chemistry_pubs

\section{Recommended Citation}

Wang, H., Vicente, M., Fronczek, F., \& Smith, K. (2014). Synthesis and transformations of 5-chloro-2,2'dipyrrins and their boron complexes, 8-chloro-BODIPYs. Chemistry - A European Journal, 20 (17), 5064-5074. https://doi.org/10.1002/chem.201304310

This Article is brought to you for free and open access by the Department of Chemistry at LSU Digital Commons. It has been accepted for inclusion in Faculty Publications by an authorized administrator of LSU Digital Commons.

For more information, please contact ir@lsu.edu. 


\title{
Synthesis and Transformations of 5-Chloro-2,2'-Dipyrrins and Their Boron Complexes, 8-Chloro-BODIPYs*
}

\author{
Haijun Wang, Prof. M. Graça H. Vicente, Dr. Frank R. Fronczek, and Prof. Kevin M. Smith \\ Department of Chemistry, Louisiana State University, Baton Rouge, LA 70803 (USA), Fax: (+1) \\ 225-578-3458
}

Kevin M. Smith: kmsmith@lsu.edu

\begin{abstract}
Symmetric dipyrrylketones 1a,b were synthesized in two steps from the corresponding a-free pyrroles, by reaction with thiophosgene followed by oxidative hydrolysis under basic conditions. The dipyrrylketones produced the corresponding 5-chloro-dipyrrinium salts or 5-ethoxy-dipyrrins on reaction with phosgene or Meerwein's salt, respectively. Boron complexation of the dipyrrins afforded the corresponding 8-functionalized BODIPYs (borondipyrromethenes) in high yields. The 5-chloro-dipyrrinium salts reacted with methoxide or ethoxide ions to produce monopyrrole esters, presumably via a 5,5-dialkoxy-dipyrromethane intermediate. In contrast, 8-chloroBODIPYs underwent a variety of nucleophilic substitutions of the chloro group in the presence of alkoxide ions, Grignard reagents, and thiols. In the presence of excess alkoxide or Grignard reagent, at room temperature or above, substitution at the boron center also occurred. The 8chloro-BODIPY was a particularly useful reagent for the preparation of 8-aryl-, 8-alkyl-, and 8vinyl-substituted BODIPYs in very high yields, using $\mathrm{Pd}^{0}$-catalyzed Stille cross-coupling reactions. The X-ray structures of eleven BODIPYs and two pyrroles are presented, and the spectroscopic properties of the synthesized BODIPYs are discussed.
\end{abstract}

\section{Keywords}

bodipy; dipyrrin; dipyrrylketone; fluorescence

\section{Introduction}

Dipyrrylketones (see Figure 1, $A$ ) have received little attention in polypyrrole chemistry. Dipyrrylketones are actually bis-vinylogous amides $\left[\nu_{\max }(\mathrm{C}=\mathrm{O}) \mathrm{ca} .1575 \mathrm{~cm}^{-1}\right]$ that do not readily react as normal ketones. For instance, dipyrrylketones are not usually reduced by borohydride. ${ }^{[1]}$ However, upon protonation they experience a significant and completely

\footnotetext{
**BODIPY=difluoroborondipyrromethene.

() 2014 Wiley-VCH Verlag GmbH\& Co. KGaA, Weinheim

Correspondence to: Kevin M. Smith, kmsmith@lsu .edu.

Supporting information for this article is available on the WWW under http://dx.doi.org/10.1002/chem.201304310 and contains ${ }^{1} \mathrm{H}$-, ${ }^{11} \mathrm{~B}$-, and ${ }^{13} \mathrm{CNMR}$ spectra, pyrrole X-ray structures and absorption/emission profiles for all BODIPYs.
} 
reversible redshift in their optical spectra $\left[\lambda_{\max }\left(\mathrm{CH}_{2} \mathrm{Cl}_{2}\right)\right.$ from 340 to $428 \mathrm{~nm}$ ], clearly demonstrating the presence of the 5-hydroxy-dipyrrylmethene salt (Figure 1,B).

Various syntheses of dipyrrylketones are well documented. The most efficient synthesis of unsymmetrical dipyrrylketones involves a modified Vilsmeier-Haack reaction that uses a 2dimethylamidopyrrole with phosphoryl chloride, and a 2-unsubstituted pyrrole as a nucleophile. ${ }^{[2]}$ Unsymmetrical dipyrrylketones can also be obtained by treatment of a pyrrole-2-acyl chloride with a pyrrole-Grignard derivative. Symmetrical dipyrroketones can be accessed by phosgenation of a pyrrole-Grignard reagent or by oxidative hydrolysis of the corresponding thioketones. ${ }^{[3]}$ Another approach to symmetrical dipyrrylketones involves direct oxidation of the 5-meso-carbon of a dipyrrylmethane by using $\mathrm{PbO}_{2} / \mathrm{Pb}(\mathrm{OAc})_{4}$ or $\mathrm{Br}_{2} /$ $\mathrm{SOCl}_{2} \cdot{ }^{[4]}$ 1,9-Diformyldipyrrylketones have been used in a MacDonald-type porphyrin synthesis to give oxyporphyrins (oxophlorins). ${ }^{[5]}$ The dipyrrylketone system is also present in b-oxobilanes, ${ }^{[6]}$ which are open-chain tetrapyrroles that can be cyclized with trimethyl orthoformate to afford oxophlorins, and subsequently, porphyrins. ${ }^{[1]}$

4,4-Difluoro-4-bora-3a,4a-diaza-s-indacenes, ${ }^{[7,8]}$ known as BODIPY dyes, have been recognized as one of the most versatile fluorophores in the last three decades because of their sharp fluorescence emissions, high quantum yields, and relatively high chemical and thermal stabilities. ${ }^{[9,10]}$ BODIPY dyes are, therefore, intensively employed as biological labeling reagents ${ }^{[11,12]}$ in protein and DNA research. BODIPYs are normally synthesized from the corresponding 2,2'-dipyrrins, also known as dipyrromethenes, upon complexation with boron, normally accomplished by the use of $\mathrm{BF}_{3} \cdot \mathrm{OEt}_{2}$ in the presence of a tertiary amine, such as $\mathrm{NEt}_{3}, 1,8$-diazabicyclo[5.4.0] undec-7-ene (DBU), or $\mathrm{N}, \mathrm{N}$ diisopropylethylamine (DIEA). The synthesis of the dipyrrin precursors usually follows a route involving acid-catalyzed condensation of two pyrroles with a carbon-linking unit; symmetric systems are normally obtained by condensation of pyrrole with an aldehyde, ${ }^{[13]}$ acyl chloride, ${ }^{[14]}$ or anhydride, ${ }^{[15]}$ whereas unsymmetrical systems are normally obtained by the condensation of a 2-formyl- or 2-acyl-pyrrole with an a-free pyrrole. ${ }^{[16]}$ Using these approaches, a variety of 8-substituted BODIPYs have been reported. An alternative synthetic route ${ }^{[17]}$ to symmetric BODIPYs is from dipyrrylketones, such as $\mathbf{1}$, which can be obtained by reaction of a pyrrole with thiophosgene, followed by oxidative hydrolysis. Dipyrrylketones are shown to be valuable intermediates in the synthesis of 5-chloro- $2,2^{\prime}$ dipyrrins and their boron complexes, which can undergo further reactions with nucleophiles. Herein, we report our results in the synthesis of 5-chloro-2,2' -dipyrrins and 8-chloroBODIPYs from dipyrrylketones, their reactions with nucleophiles, and their use in $\mathrm{Pd}^{0}$ catalyzed cross-coupling reactions. This work advances previous knowledge ${ }^{[17]}$ by reporting new chemistry of 5-chloro-dipyrrins (including a novel fragmentation reaction), describing reactions of 8-chloro-BODIPYs with carbon nucleophiles, and reporting highly efficient organotin reactions.

\section{Results and Discussion}

Symmetric dipyrrylketones 1a,b were obtained in two steps (Scheme 1) by treatment of the corresponding a-free pyrrole $\mathbf{2} \mathbf{a}, \mathbf{b}$ with thiophosgene, followed by oxidative hydrolysis of the resulting dipyrrylthioketone. ${ }^{[3,18,19]}$ Alternatively, the dipyrrylketones could be 
obtained in similar overall yields by reaction of a 2- $\mathrm{N}, \mathrm{N}$-dimethylamidopyrrole with excess phosphoryl chloride, followed by treatment with pyrroles unsubstituted at the 2-position, such as $\mathbf{2 a}, \mathbf{b}$, and then $10 \%$ aqueous $\mathrm{Na}_{2} \mathrm{CO}_{3}$. The dipyrrylketones were characterized by FTIR because they show a characteristic band for the amide-like 5-carbonyl group at approximately $v=1575 \mathrm{~cm}^{-1}$ in chloroform, and by HRMS (ESI), and ${ }^{1} \mathrm{H}-$ and ${ }^{13} \mathrm{C}$ NMR spectroscopies. Dipyrrylketones 1a,b were 5-chlorinated ${ }^{[20]}$ in $91-93 \%$ yields by reaction with phosgene in dichloromethane or chloroform, to give the corresponding 5-chlorodipyrrin salts 3a,b. Other chlorinating agents, including $\mathrm{POCl}_{3}$ and $(\mathrm{COCl})_{2}$, also gave the desired products, although in lower yields. The 5-chloro-dipyrrins $\mathbf{3 a}$ and $\mathbf{3 b}$ showed characteristic UV/Vis absorptions at $\lambda_{\max }=485$ and $505 \mathrm{~nm}$ in dichloromethane, respectively, and were also characterized by their HRMS (ESI) and ${ }^{1} \mathrm{H}$ and ${ }^{13} \mathrm{C}$ NMR spectra. Complexation of the 5-chloro-dipyrrins $\mathbf{3 a}, \mathbf{b}$ with boron, by using $\mathrm{BF}_{3} \cdot \mathrm{OEt}_{2}$ under basic conditions, gave the corresponding BODIPYs $\mathbf{4 a}, \mathbf{b}$ in $94-96 \%$ yield. Compounds $\mathbf{4 a}$ and $\mathbf{4 b}$ were characterized by strong UV/Vis absorptions at 503 and $527 \mathrm{~nm}$ and brighter fluorescence emissions at 512 and $542 \mathrm{~nm}$, respectively. Single crystals suitable for X-ray structure analysis were obtained for both 8-chloro-BODIPYs 4a,b (Figure 2). The nonhydrogen atoms, except for fluorine in $\mathbf{4 a}$, are fairly coplanar, with a mean deviation of $0.052 \AA$, and the $\mathrm{BF}_{2}$ plane is almost orthogonal, with a dihedral angle of $89.88(2)^{\circ}$. Compound $\mathbf{4 b}$ has three molecules in the asymmetric unit, two of which have the ethyl groups relatively syn, and one has an anti ethyl group. Analogous dihedral angles in the three molecules are in the range $88.45(2)-89.37(2)^{\circ}$. BODIPYs 5a,b were also obtained from dipyrrylketones 1a,b upon reaction with Meerwein's salt (triethyloxonium tetrafluoroborate). ${ }^{[21]}$ Treatment of $\mathbf{1 a}$ and $\mathbf{1 b}$ with Meerwein's salt in chloroform, at room temperature, gave orange-red colored solutions, indicating the formation of the fully conjugated 5-ethoxy-dipyrrins. After aqueous workup, the crude residues were complexed with boron by using similar conditions to those reported above, to produce BODIPYs $\mathbf{5 a} \mathbf{a}, \mathbf{b}$ in 71-82\% overall yields (Scheme 1). BODIPYs $\mathbf{5 a}, \mathbf{b}$ could also be obtained from $\mathbf{4 a}, \mathbf{b}$, but in lower yield (46-52\%), by nucleophilic addition/elimination of the 8-chloro group, by using sodium ethoxide in ethanol (see below). BODIPYs $\mathbf{5 a}, \mathbf{b}$ showed intense UV/Vis absorptions at 487 and $508 \mathrm{~nm}$, respectively, and characteristic resonances for the ethoxy group in their ${ }^{1} \mathrm{H}$ NMR spectra at approximately $\delta=4.12$ (q) and 1.53 (t) ppm. The molecular X-ray structures for both BODIPYs 5a,b were also obtained (Figure 2). Molecule 5a almost has $C_{\mathrm{s}}$ symmetry, with the $\mathrm{BF}_{2}$ plane and dipyrryl plane forming a dihedral angle of $89.37(4)^{\circ}$, and the atoms of the OEt group lying at mean of $0.012 \AA$ from the $\mathrm{BF}_{2}$ plane; $\mathbf{5 b}$ has a similar structure, with a dihedral angle of $88.68(1)^{\circ}$, but the dipyrryl ethyl groups are anti to each other.

The reactions of 5-chloro-dipyrrinium 3a and BODIPY $\mathbf{4 a}$ in the presence of nucleophiles were further investigated. In the presence of sodium methoxide in methanol, THF, or chloroform, compound 3a, surprisingly, produced the monopyrrole methyl ester $\mathbf{6}$ in $81 \%$ yield (Scheme 1). If sodium ethoxide was used, the corresponding ethyl ester 7 was obtained (66\% yield). The reaction was followed by UV/Vis spectroscopy until complete disappearance of the absorption band of the 5-chloro-dipyrrin occurred. Pyrroles 6 and $\mathbf{7}$ were fully characterized, including by X-ray crystallography (see the Supporting Information). Two oxygen atoms are added in this unprecedented dipyrrole cleavage 
reaction to form 6 or 7, therefore, it is suggested that intermediate 5,5-

dimethoxydipyrromethane $\mathbf{8}$ is involved (Scheme 2), and this intermediate undergoes a basecatalyzed version of the known pyrrole deacylation reaction to give $\mathbf{6}$ or $\mathbf{7}$ and the corresponding 2-unsubstituted pyrrole. ${ }^{[22]}$ Weaker nucleophiles, including $\mathrm{KCN}$ and $n \mathrm{Bu}_{4} \mathrm{NF}$, did not produce any substitution product. However, the 5-chlorodipyrrin 3a reacted with ethyl magnesium bromide in THF, at room temperature or under reflux, to give a mixture of the desired 5-ethyl-dipyrrin $\mathbf{9}$ and the reduced meso-free compound $\mathbf{1 0}$ (Scheme 3 ), which could not be separated by chromatography. Complexation of the mixture with boron by using $\mathrm{BF}_{3} \cdot \mathrm{OEt}_{2}$ in DIEA produced the corresponding BODIPYs in 20 and $53 \%$ yields, respectively, after separation. BODIPY 11 was obtained in higher yield (75\%) by reaction of $4 \mathbf{a}$ with ethyl magnesium bromide in THF at $-78^{\circ} \mathrm{C}$; in this case only $10 \%$ of the 8 -unsubstituted BODIPY was isolated. When the reaction was performed at $0{ }^{\circ} \mathrm{C}$ and the mixture was warmed up to room temperature, ${ }^{[23-25]}$ the triethyl substituted BODIPY, 12, was the only product obtained, in 83\% yield. Both BODIPYs $\mathbf{1 1}$ and $\mathbf{1 2}$ had characteristic UV/Vis absorptions, both at $499 \mathrm{~nm}$, and $\mathrm{m} / z$ at 276.1713 and 296.2507 , respectively. The ${ }^{1} \mathrm{H}$ NMR spectra of BODIPYs $\mathbf{1 1}$ and $\mathbf{1 2}$ showed the characteristic 8-ethyl protons centered at $\delta=3.01$ (q) and 1.31 (t) ppm, respectively; the B-ethyl protons of BODIPY 12 appeared as broad signals at $\delta=0.79$ and $0.30 \mathrm{ppm}$.

Because the 8-chloro-BODIPY 4a gave higher yields for the substitution products compared with dipyrrin 3a, owing to the higher stability of the BODIPY core and easier product purification, additional substitution reactions were investigated for $\mathbf{4 a}$, as shown in Scheme 4 and Table 1. Reaction of BODIPY $4 \mathbf{a}$ with sodium methoxide in methanol at room temperature produced the corresponding substitution product 13 in $67 \%$ yield, along with dimethoxy (21\%) and trimethoxy (very minor) side products, in which one or both the fluorine atoms were also replaced. ${ }^{[26]}$ When the reaction was performed at $80^{\circ} \mathrm{C}$ trimethoxyBODIPY 15 was the major product, isolated in $65 \%$ yield along with the dimethoxy side product in $16 \%$ yield. BODIPY $\mathbf{1 4}$ was prepared in $81 \%$ yield by reaction of $\mathbf{4 a}$ with sodium phenoxide at room temperature in THF. Both BODIPYs $\mathbf{5 a}$ and $\mathbf{1 3}$ showed significantly blueshifted UV/Vis absorptions, both centered at $487 \mathrm{~nm}$, and for $\mathbf{1 4}$ at $491 \mathrm{~nm}$, compared with the starting BODIPY 4a. However, substitution of the fluorine atoms, as in BODIPY 15, had no significant effect on the $\lambda_{\max }$ value, as previously observed. The ${ }^{1} \mathrm{H}$ NMR spectra of BODIPYs 13 and $\mathbf{1 5}$ showed the 8-OMe protons at $\delta=3.98$ and $3.97 \mathrm{ppm}$, respectively, whereas the B-OMe protons of $\mathbf{1 5}$ appeared at $\delta=2.89 \mathrm{ppm}$. Two sulfur nucleophiles were also reacted with BODIPY $4 \mathbf{a}$, in THF and in the presence of $\mathrm{K}_{2} \mathrm{CO}_{3}$ as the base (Scheme 4). 2-Mercaptobenzothiazole gave BODIPY 16 in 56\% yield, whereas 1mercaptomethyl-p-carborane ${ }^{[27]}$ gave 17 in $92 \%$ yield. BODIPYs 16 and 17 showed redshifted UV/Vis absorptions at 539 and $529 \mathrm{~nm}$, respectively. The ${ }^{1} \mathrm{H}$ NMR spectra of these BODIPYs showed the aromatic protons of $\mathbf{1 6}$ at $\delta=7.28-7.98 \mathrm{ppm}$ and the $\mathrm{SCH}_{2}$ protons of 17 at $\delta=2.95 \mathrm{ppm}$. Both BODIPYs 16 and 17 were characterized by X-ray crystallography (Figure 2). In BODIPY 16, the dipyrryl and $\mathrm{BF}_{2}$ planes form a dihedral angle of $88.03(7)^{\circ}$, whereas the mercaptobenzothiazole plane forms a dihedral angle of $77.03(2)^{\circ}$ with the dipyrryl unit. In BODIPY 17 , the dipyrryl and $\mathrm{BF}_{2}$ planes form a dihedral angle of $88.8(1)^{\circ}$, the linkage between dipyrryl and para-carborane is extended, with a C-S- 
$\mathrm{CH}_{2}-\mathrm{C}$ torsion angle of $175.3(6)^{\circ}$. The best plane of the CSCC linkage forms a dihedral angle of $83.8(2)^{\circ}$ with the dipyrryl plane.

Though 8-chloro-BODIPYs react efficiently in nucleophilic addition-elimination reactions with strong nucleophiles (Scheme 4 and [17]), the 8-chloro-BODIPY 4a was unreactive in the presence of weaker nucleophiles, such as $\mathrm{KCN}$ and $n \mathrm{Bu}_{4} \mathrm{NF}$.

$\mathrm{Pd}^{0}$-catalyzed cross-coupling procedures on BODIPYs have been explored, including the Suzuki, ${ }^{[28]}$ Stille, ${ }^{[29]}$ Heck, ${ }^{[30]}$ and Sonogoshira ${ }^{[31]}$ reactions. These transformations have been performed either directly on the BODIPY core ${ }^{[32-35]}$ or on a substituent, ${ }^{[36]}$ and have facilitated the functionalization of BODIPYs, especially coupling reactions of 3,5- and 2,6dihalogenated-BODIPYs. In comparison with the pyrrolic positions, the meso-carbon is more electrophilic, as suggested by Mulliken charge distribution and reactivity studies. ${ }^{[37]}$ Recently, various $\mathrm{Pd}^{0}$-catalyzed cross-coupling reactions were performed on 8-haloBODIPYs ${ }^{[17]}$ with arylboronic acids or aryltin reagents under Suzuki or Stille conditions, and with phenylacetylene under Sonogashira conditions. The products from these reactions were obtained in 36-76\% yields, with the lowest yield obtained for the 8-chloro-BODIPY under Suzuki conditions. Concurrently, we were also investigating the $\mathrm{Pd}^{0}$-catalyzed coupling reactions of 8-chloro-BODIPY $\mathbf{4 a}$ and the effect of the 1,7-methyl groups on the cross-coupling reactions. A Suzuki reaction ${ }^{[38]}$ between 8 -chloro-BODIPY $4 \mathbf{a}$ and phenylboronic acid using $\left[\mathrm{Pd}\left(\mathrm{PPh}_{3}\right)_{4}\right]$ as the catalyst and $\mathrm{K}_{2} \mathrm{CO}_{3}$ as the base in 1,2dimethoxyethane (DME), at reflux for $24 \mathrm{~h}$, produced the 8-phenyl-BODIPY 18 in $47 \%$ yield. A side product from this reaction was the corresponding meso-unsubstituted BODIPY, along with other pyrrolic byproducts from loss of the $\mathrm{BF}_{2}$ moiety under the relatively harsh conditions. BODIPY 18 was synthesized in higher yield (see Table 1) under milder Stille cross-coupling conditions ${ }^{[39]}$ by using tributylphenylstannane and $\left[\mathrm{Pd}\left(\mathrm{PPh}_{3}\right)_{4}\right]$, without any base. The reaction mixture was heated at reflux in toluene and TLC analysis indicated that the reaction was complete within five hours, having proceeded in almost quantitative yield. Therefore, we investigated additional $\mathrm{Pd}^{0}$-catalyzed Stille cross-coupling reactions of 8chloro-BODIPY 4a (Table 1). Various organotin reagents bearing alkyl, alkenyl, alkynyl, and heterocyclic aromatic groups were used in the cross-coupling reactions. All of the coupling reactions produced the corresponding 8-functionalized BODIPYs in almost quantitative yields, except for the reaction with tributylethynyltin, which produced BODIPY 22 in only $31 \%$ yield. ${ }^{[40]}$ However, use of the trimethylsilyl-protected organotin reagent afforded a $71 \%$ yield of the trimethylsilylalkyne substituted BODIPY 23. The yields for the alkynyl derivatives $\mathbf{2 2}$ and $\mathbf{2 3}$ are lower than for all other coupling products (Table 1), particularly for $\mathbf{2 2}$, probably because of the higher reactivity of the unprotected mesoalkynyl group.

The structures of BODIPYs 18-25 were confirmed by ${ }^{1} \mathrm{H}$ and ${ }^{13} \mathrm{C}$ NMR spectroscopy, HRMS (ESI-TOF) mass spectrometry, UV/Vis spectroscopy, and X-ray crystallography (Figure 2); BODIPYs 12, 15 and the mono MeO-B-F compound were also investigated by using ${ }^{11} \mathrm{~B}$ NMR spectroscopy. The ${ }^{1} \mathrm{H}$ NMR spectrum of 8-phenyl-BODIPY 18 showed aromatic protons between $\delta=7.27-7.49 \mathrm{ppm}$, consistent with literature reports, ${ }^{[41]}$ and a $m / z$ peak at 324.1717 in the mass spectrum. The meso-methyl group of BODIPY 19 appeared at $\delta=2.40 \mathrm{ppm}$ in its ${ }^{1} \mathrm{H}$ NMR spectrum and the product showed a $\mathrm{m} / z$ peck at 262.1556 in the 
mass spectrum. For BODIPYs 20 and 21, the ${ }^{1} \mathrm{H}$ NMR spectrum showed the alkene protons at $\delta=5.56(\mathrm{~d}), 5.69(\mathrm{~d})$, and 6.74 (dd) ppm or as two doublets at $\delta=4.38(\mathrm{~d})$ and $4.50(\mathrm{~d}) \mathrm{ppm}$, respectively. The ethoxy group of $\mathbf{2 1}$ produced signals at $\delta=3.89(\mathrm{q})$ and $1.39(\mathrm{t}) \mathrm{ppm}$ in the ${ }^{1} \mathrm{H}$ NMR spectrum and the mass spectra for BODIPYs 20 and $\mathbf{2 1}$ showed $\mathrm{m} / \mathrm{z}$ at 274.1557 and 318.1817, respectively. BODIPY 22 showed a typical peak at $\delta=3.92 \mathrm{ppm}$ for the terminal alkynyl proton (absent in 23) in its ${ }^{1} \mathrm{H}$ NMR spectrum, and $m / z$ at 272.1380 .

The meso-rings of BODIPYs 24 and 25 showed peaks between $\delta=6.06-6.77$ and 6.98-7.51 ppm, respectively, and the $N-\mathrm{CH}_{3}$ of $\mathbf{2 4}$ showed a peak at $\delta=3.40 \mathrm{ppm}$ in the ${ }^{1} \mathrm{H}$ NMR spectra. These two BODIPYs were also characterized by $\mathrm{m} / \mathrm{z}$ at 327.1799 and 352.1094 , respectively. The X-ray crystal structures of BODIPYs 18, 19, 20, 24, and 25 were obtained by slow diffusion of hexane into a dichloromethane solution, and are shown in Figure 2. BODIPY 18 deviates from its potential $C_{\mathrm{S}}$ symmetry because the $\mathrm{BF}_{2}$ and phenyl planes are twisted in opposite directions, away from orthogonality with the dipyrryl plane. The $\mathrm{BF}_{2}$ moiety forms a dihedral angle of $88.13(5)^{\circ}$ and the phenyl moiety a dihedral angle of $82.40(3)^{\circ}$. BODIPY 19 is unusual in that its dipyrryl group lies in a crystallographic mirror and its $\mathrm{BF}_{2}$ group lies across it; thus, they are exactly orthogonal. The $\mathrm{X}$-ray structure for BODIPY 20 was also obtained (Figure 2). Its dipyrryl and $\mathrm{BF}_{2}$ planes form a dihedral angle of $88.82(2)^{\circ}$. The ethene substituent is not quite orthogonal to the dipyrryl nor coplanar with the $\mathrm{BF}_{2}$ moiety, a $\mathrm{C}-\mathrm{C}-\mathrm{C}=\mathrm{C}$ torsion angle about the bond being $72.65(10)^{\circ}$. BODIPY 24 deviates only slightly from $C_{s}$ symmetry, with the $\mathrm{BF}_{2}$ plane forming a dihedral angle of $89.51(9)^{\circ}$ with the dipyrryl plane and the methylpyrrole plane forming an angle of $85.77(4)^{\circ}$ with it. In Figure 2, only one of the major orientations of the disordered thiophene is shown for BODIPY 25; it forms a dihedral angle of $84.31(8)^{\circ}$ with dipyrryl, and the $\mathrm{BF}_{2}$ plane forms a dihedral angle of $88.56(4)^{\circ}$ with the dipyrryl plane.

The spectroscopic properties of the BODIPYs were investigated and their UV/Vis absorption and steady-state fluorescence emission spectra in dichloromethane were recorded. As an example, Figure 3 shows the normalized absorption and fluorescence spectra of BODIPYs 4a, 5a, and 22 (see the Supporting Information for all other BODIPY spectra). Table 2 summarizes the spectroscopic data obtained for the BODIPYs, including their maximum absorption and fluorescence wavelengths, molar extinction coefficients, and fluorescence quantum yields in dichloromethane. As expected, literature compounds $\mathbf{1 8}$ and 19 showed absorption and emission profiles similar to those previously reported. ${ }^{[42]}$ The new BODIPYs, $\mathbf{4} \mathbf{a}$ and $\mathbf{4} \mathbf{b}$, show spectra of comparable shape and characteristics to other BODIPYs described in the literature, with a strong absorption band corresponding to the $\mathrm{S}_{0^{-}}$ $\mathrm{S}_{1}\left(\pi-\pi^{*}\right)$ transitions centered at 503 and $527 \mathrm{~nm}$, respectively. The approximate $25 \mathrm{~nm}$ redshift observed in the absorption and emission maxima is due to the increased alkyl substitution of the BODIPY core (i.e., the 2,6-diethyl substituents in $\mathbf{4 b}$ and $\mathbf{5 b}$ ). ${ }^{[41]}$ The replacement of the 8-chloro group on BODIPY $\mathbf{4 a}$ with an alkyl (11 and 19), alkoxy (5a and 13), or phenoxy (14) moiety caused blueshifts of the absorption and emission maxima in the order of 16-19 nm for the alkoxy-BODIPYs, 12-13 nm for the aryloxy-BODIPY and 4-7 $\mathrm{nm}$ for the alkyl-BODIPYs. On the other hand, substitution with a phenyl (18) or vinyl (20) group had no noticeable effect on the absorption and emission wavelengths, whereas $\approx 10$ $\mathrm{nm}$ redshifts were observed for BODIPYs $\mathbf{2 1}, \mathbf{2 4}$, and 25, and the largest redshifts were obtained for the meso-thio (16) and meso-alkynyl (22) BODIPYs ( $\approx 40 \mathrm{~nm}$ ). The 
fluorescence quantum yields for BODIPYs $\mathbf{4 a}$ and $\mathbf{4 b}$ were found to be 0.51 and 0.33 , respectively, owing to the heavy-atom effect of the chlorine and introduction of the two ethyl groups in $\mathbf{4 b}$. In accordance with the literature, ${ }^{[17]}$ replacement of the meso-chloro with an alkoxy or phenoxy group caused a significant increase in quantum yield, particularly for BODIPYs 5a and $14\left(\Phi_{\mathrm{f}} \approx 1.0\right)$, whereas substitution with a meso-thiol had the opposite effect, $\Phi_{\mathrm{f}}$ of 0.04 and 0.09 were found for BODIPYs 16 and 17, respectively. Substitution of the 8-chloro group with an alkyl (methyl and ethyl) or phenyl group also increased the quantum yields to $\Phi_{\mathrm{f}} \approx 0.8$ (for $\mathbf{1 1}$ and 19 ) and 0.62 for $\mathbf{1 8}$. However, the quantum yields for the meso-alkenyl, alkynyl, pyrrolyl, and thienyl-BODIPYs 20-25 were appreciably lower, particularly for $\mathbf{2 0}$, the fluorescence of which was essentially quenched, due to the greater freedom of rotation for these smaller groups increasing the energy lost to non-radiative decay. ${ }^{[43]}$ Boron substitution had no significant effect on the absorption and emission wavelengths, but did influence the fluorescence quantum yield. Although boron substitution with two methoxy groups significantly increased the quantum yield of BODIPY 15 ( $\left.\Phi_{\mathrm{f}}=1.0\right)$ relative to 13 ( $\left.\Phi_{\mathrm{f}}=0.57\right)$, substitution with two ethyl groups reduced the quantum yield of BODIPY $12\left(\Phi_{\mathrm{f}}=0.32\right)$ relative to $\mathbf{1 1}\left(\Phi_{\mathrm{f}}=0.83\right)$.

\section{Conclusion}

The synthesis of BODIPY dyes from dipyrrylketone precursors has been explored. New BODIPY compounds were obtained that are usually very difficult to synthesize by conventional methods. The transformation of dipyrrylketones into 5-chlorodipyrrins was studied, and further reactions involving electrophilic, nucleophilic addition/elimination, and coupling reactions were reported. In this context an unexpected cleavage reaction of 5chloro-dipyrrins to give monopyrrole-2-carboxylates was discovered. The use 5-chlorodipyrrins represents an alternative method with broad applicability for the modification of BODIPYs, especially at their 8-meso-carbon. Variations in the photophysical properties of the various new BODIPYs are discussed and interpreted, emphasizing the significant effect caused by meso-substitution. Finally, the X-ray structures of eleven BODIPYs are reported and analyzed within the context of BODIPY solid-state structural characteristics.

\section{Experimental Section}

\section{General}

Commercially available reagents were purchased from Sigma-Aldrich Co., and were used without further purification. All air and moisture sensitive reactions were performed under an argon atmosphere Melting points were measured on an Electrothermal MEL-TEMP instrument. Analytical thin-layer chromatography (TLC) was performed on polyester backed TLC plates 254 (precoated, $200 \mu \mathrm{m}$, Sorbent Technologies). Column chromatography was performed on silica gel (Sorbent Technologies, $60 \AA$, 40-63 $\mu \mathrm{m}$ ) ${ }^{1} \mathrm{H}-,{ }^{13} \mathrm{C}$ - and ${ }^{11} \mathrm{~B}$ NMR spectra were recorded, by using a Bruker AV-400 spectrometer, in $\mathrm{CDCl}_{3}\left(7.26 \mathrm{ppm},{ }^{1} \mathrm{H}\right.$ and $77.0 \mathrm{ppm},{ }^{13} \mathrm{C}$, and $\mathrm{BF}_{3} \cdot \mathrm{Et}_{2} \mathrm{O}$ at $\left.0.0 \mathrm{ppm},{ }^{11} \mathrm{~B}\right)$. Chemical shifts are given in parts per millions (ppm) relative to tetramethylsilane (TMS, $0 \mathrm{ppm}$ ); multiplicities are indicated as br (broad), s (singlet), d (doublet), t (triplet), q (quartet) and m (multiplet). All spectra were 
recorded at room temperature. Mass spectra were obtained at the LSU Department of Chemistry Mass Spectrometry Facility using an Applied Biosystems QSTAR XL ESI-TOF.

1,3,7,9-Tetramethyldipyrryl-5-ketone 1a-A solution of thiophosgene (1.15 g, 10.0 $\mathrm{mmol})$ in toluene $(10 \mathrm{~mL})$ was added dropwise to a solution of 2,4-dimethylpyrrole $(2.0 \mathrm{~g}$, $21.0 \mathrm{mmol}$ ) in dry ether $(30 \mathrm{~mL})$ at $0{ }^{\circ} \mathrm{C}$. The mixture was stirred for about $1 \mathrm{~h}$ (until TLC analysis showed the starting material had disappeared). Then, methanol $(30 \mathrm{~mL})$ was added and the reaction mixture was stirred for another $30 \mathrm{~min}$. The solvents were removed in vacuo and the residue was purified on a silica-gel column eluted with toluene/chloroform (4:1). The thioketone product was obtained as an orange solid. (980 mg, 40\%); m.p. 180$181{ }^{\circ} \mathrm{C} ;{ }^{1} \mathrm{H}$ NMR $\left(400 \mathrm{MHz} ; \mathrm{CDCl}_{3}\right.$ ): $\delta=8.96$ (s, 2H), 5.91 (s, 2H), 2.27 (s, 6H), $2.07 \mathrm{ppm}$ (s, $6 \mathrm{H}) ;{ }^{13} \mathrm{C} \mathrm{NMR}\left(100 \mathrm{MHz} ; \mathrm{CDCl}_{3}\right): \delta=175.30,133.30,127.98,127.56,111.74,13.09$, 12.65 ppm; HRMS (ESI): $\mathrm{m} / z$ calcd for $\mathrm{C}_{13} \mathrm{H}_{16} \mathrm{~N}_{2} \mathrm{~S}: 233.1107\left[M+\mathrm{H}^{+}\right]$; found: 233.1106 . To the thioketone $(232 \mathrm{mg}, 1.0 \mathrm{mmol})$ in $\mathrm{EtOH}(95 \%, 100 \mathrm{~mL})$ was added $\mathrm{KOH}(1.0 \mathrm{~g})$, and to this mixture was added aqueous $\mathrm{H}_{2} \mathrm{O}_{2}(5 \%, 10 \mathrm{~mL})$ dropwise in an ice bath. Then, the solution was heated in a steam bath for about $5 \mathrm{~min}$. The solution was cooled to room temperature and water $(300 \mathrm{~mL})$ was added and the solution was extracted with chloroform three times. The organic layers were collected and washed with water, brine and then dried over anhydrous $\mathrm{Na}_{2} \mathrm{SO}_{4}$. The solvent was evaporated and the residue was purified by sublimation to give the product dipyrrylketone as a pale yellow solid. (170 mg, 78\%); m.p. 232-233 ${ }^{\circ} \mathrm{C} ;{ }^{1} \mathrm{H}$ NMR $\left(400 \mathrm{MHz} ; \mathrm{CDCl}_{3}\right): \delta=8.63(\mathrm{~s}, 2 \mathrm{H}), 5.85(\mathrm{~s}, 2 \mathrm{H}), 2.28(\mathrm{~s}, 6 \mathrm{H}), 2.19$ ppm (s, 6H); $\left.{ }^{13} \mathrm{C} \mathrm{NMR} \mathrm{(100} \mathrm{MHz;} \mathrm{CDCl}_{3}\right): \delta=175.30,133.30,127.98,127.56,111.74$, $13.09,12.65 \mathrm{ppm}$; IR $\tilde{\nu}_{\max }(\mathrm{C}=\mathrm{O})(\mathrm{Nujol})=1573 \mathrm{~cm}^{-1}$; UV/Vis $\left(\mathrm{CH}_{2} \mathrm{Cl}_{2}\right): \lambda_{\max }(\varepsilon)=295$ (8600), $341 \mathrm{~nm}(14600)$; HRMS (ESI): $m / z$ calcd for $\mathrm{C}_{13} \mathrm{H}_{16} \mathrm{~N}_{2} \mathrm{O}: 217.1335\left[M+\mathrm{H}^{+}\right]$; found: 217.1334 .

\section{2,8-Diethyl-1,3,7,9-tetramethyl-5-dipyrrylketone 1b}

Method A: 4-Ethyl-3,5-dimethylpyrrole-2-dimethylamide (8.0 g. $41.2 \mathrm{mmol}$ ) was dissolved in excess $\mathrm{POCl}_{3}$ and warmed at $50^{\circ} \mathrm{C}$ for $15 \mathrm{~min}$ before being evaporated to dryness. The resulting complex $\left(\lambda_{\max }=380 \mathrm{~nm}\right)$ was taken up in $\mathrm{CH}_{2} \mathrm{Cl}_{2}(20 \mathrm{~mL})$. 3-Ethyl-2,4dimethylpyrrole ( $5.6 \mathrm{~g}, 45.5 \mathrm{mmol}$ ) was then added and the mixture was heated under reflux for 90 min. The brown solution $\left(\lambda_{\max }=408 \mathrm{~nm}\right)$ was stirred vigorously with $10 \%$ aq $\mathrm{Na}_{2} \mathrm{CO}_{3}$ $(100 \mathrm{~mL})$ and heated under reflux for $2 \mathrm{~h}$. The dipyrrylketone product, precipitated from solution as a yellow solid, was filtered off and the organic layer was separated. The aqueous layer was extracted with $\mathrm{CH}_{2} \mathrm{Cl}_{2}(50 \mathrm{~mL})$ and the combined organic extracts were washed with water and dried over anhydrous $\mathrm{MgSO}_{4}$ before evaporation to small volume. The yellow solid that precipitated was combined with the earlier solid and was recrystallized from $\mathrm{CH}_{2} \mathrm{Cl}_{2}$ to give $\mathbf{1 b}(10.1 \mathrm{~g}, 89 \%)$ as pale yellow needles.

Method B: The synthesis of $\mathbf{1 b}$ followed the procedure reported above for 1a. Thioketone yield: (1.30 g, 43\%); m.p. $\left.172-174{ }^{\circ} \mathrm{C} ;{ }^{1} \mathrm{H} \mathrm{NMR} \mathrm{(400} \mathrm{MHz;} \mathrm{CDCl}_{3}\right): \delta=8.95$ (s, $\left.2 \mathrm{H}\right), 2.37$ (q, $J=7.5 \mathrm{~Hz}, 4 \mathrm{H}), 2.23$ (s, 6H), $2.00(\mathrm{~s}, 6 \mathrm{H}), 1.05 \mathrm{ppm}(\mathrm{t}, J=7.5 \mathrm{~Hz}, 6 \mathrm{H}) ;{ }^{13} \mathrm{C}$ NMR $(100$ $\mathrm{MHz} ; \mathrm{CDCl}_{3}$ ): $\delta=189.39,136.19,134.67,126.67,125.56,17.47,14.99,11.73,10.88$ ppm; HRMS (ESI): $\mathrm{m} / z$ calcd for $\mathrm{C}_{17} \mathrm{H}_{25} \mathrm{~N}_{2} \mathrm{~S}: 289.1733\left[M+\mathrm{H}^{+}\right]$; found: 289.1739 .

Dipyrrylketone 1b yield: (224 mg, 82\%); m.p. $205-207^{\circ} \mathrm{C}$ (literature ${ }^{[41]} 207^{\circ} \mathrm{C}$ ); ${ }^{1} \mathrm{H}$ NMR 
(400 MHz; $\mathrm{CDCl}_{3}$ ): $\delta=8.61$ (s, 2H), 2.40 (q, J=7.5 Hz, 4H), 2.23 (s, 6H), 2.14 (s, 6H), 1.07 ppm (t, $J=7.5 \mathrm{~Hz}, 6 \mathrm{H}) ;{ }^{13} \mathrm{C}$ NMR $\left(100 \mathrm{MHz} ; \mathrm{CDCl}_{3}\right): \delta=175.23,129.65,127.24,125.27$, $124.25,17.37,15.20,11.41,10.70 \mathrm{ppm}$; IR $\tilde{v}_{\max }(\mathrm{C}=\mathrm{O})\left(\mathrm{CHCl}_{3}\right.$ or $\left.\mathrm{Nujol}\right)=1575 \mathrm{~cm}^{-1}$; UV/Vis $\left(\mathrm{CHCl}_{3}\right): \lambda_{\max }(\varepsilon)=288$ (11700), $357 \mathrm{~nm}(25000)$; HRMS (ESI): $\mathrm{m} / z$ calcd for $\mathrm{C}_{17} \mathrm{H}_{25} \mathrm{~N}_{2} \mathrm{O}: 273.1967\left[M+\mathrm{H}^{+}\right]$; found: 273.2013.

5-Chloro-1,3,7,9-tetramethyldipyrromethene hydrochloride 3a-Dipyrrylketone 1a (314 mg, $1.45 \mathrm{mmol}$ ) was dissolved in $\mathrm{CHCl}_{3}$ and phosgene in toluene solution was added before stirring at room temperature for $1 \mathrm{~h}$. When the reaction was complete according to UV/Vis spectroscopy and TLC analysis, nitrogen gas was passed through solution to purge it of excess phosgene, which was directed to a $\mathrm{NaHCO}_{3}$ solution trap. Solvent was then removed in vacuo and the red solid was recrystallized from $\mathrm{CHCl}_{3} /$ petroleum ether to give 3a as a red solid $(356 \mathrm{mg}, 91 \%)$; m.p.> 260 ${ }^{\circ}$; ${ }^{1} \mathrm{H} \mathrm{NMR}(400 \mathrm{MHz}$; $\mathrm{CDCl}_{3}$ ): $\delta=12.93$ (s, 2H), 6.23 (s, 2H), 2.59 (s, 6H), 2.34 ppm (s, 6H); ${ }^{13} \mathrm{C} \mathrm{NMR} \mathrm{(100} \mathrm{MHz;}$ $\left.\mathrm{CDCl}_{3}\right): \delta=153.70,144.35,139.63,128.18,120.71,16.27,14.38 \mathrm{ppm}$; UV/Vis $\left(\mathrm{CH}_{2} \mathrm{Cl}_{2}\right)$ : $\lambda_{\max }(\varepsilon)=485 \mathrm{~nm}(23500)$; HRMS (ESI): $m / z$ calcd for $\mathrm{C}_{13} \mathrm{H}_{16} \mathrm{ClN}_{2}$ : 235.0997; found: 235.0992 .

\section{5-Chloro-2,8-diethyl-1,3,7,9-tetramethyldipyrromethene hydrochloride $\mathbf{3 b}$ -}

Yield: (439 mg, 93\%); m.p. $>300^{\circ} \mathrm{C}$; ${ }^{1} \mathrm{H}$ NMR $\left(400 \mathrm{MHz} ; \mathrm{CDCl}_{3}\right): \delta=12.50$ (s, 2H), 2.35 (s, $6 \mathrm{H}), 2.15$ (s, 6H), 2.40 (q, $J=7.6 \mathrm{~Hz}, 4 \mathrm{H}), 1.05 \mathrm{ppm}(\mathrm{t}, J=7.6 \mathrm{~Hz}, 6 \mathrm{H}) ;{ }^{13} \mathrm{C}$ NMR $(100 \mathrm{MHz}$; $\left.\mathrm{CDCl}_{3}\right): \delta=152.41,138.81,137.68,133.13,128.08,17.44,14.28,12.72,12.63 \mathrm{ppm}$; UV/Vis $\left(\mathrm{CH}_{2} \mathrm{Cl}_{2}\right): \lambda_{\max }(\varepsilon)=509 \mathrm{~nm}\left(57\right.$ 500); HRMS (ESI): $\mathrm{m} / z$ calcd for $\mathrm{C}_{17} \mathrm{H}_{24} \mathrm{ClN}_{2}: 291.1623$; found: 291.1635; elemental analysis calcd (\%) for $\mathrm{C}_{17} \mathrm{H}_{24} \mathrm{Cl}_{2} \mathrm{~N}_{2}$ : C 62.4, $\mathrm{H}$ 7.3, N 8.6; found: C 62.7, H 7.5, N 8.8.

BODIPY 4a: Chloro-dipyrrin hydrochloride $3 \mathbf{a}(235 \mathrm{mg}, 0.87 \mathrm{mmol})$ was dissolved in $\mathrm{CHCl}_{3}$ and DIEA ( $8 \mathrm{mmol}$, 9.0 equiv) was added before the mixture was stirred for $30 \mathrm{~min}$. Then, $\mathrm{BF}_{3} \cdot \mathrm{OEt}_{2}$ ( $14 \mathrm{mmol}, 16$ equiv) was added. The resulting mixture was stirred overnight at room temperature. The solution was washed with saturated aq $\mathrm{NaHCO}_{3}$, brine and then dried over anhydrous $\mathrm{Na}_{2} \mathrm{SO}_{4}$. The solvent was evaporated and the residue was purified by chromatography on silica gel (eluted with $\mathrm{CH}_{2} \mathrm{Cl}_{2}$ /hexane) to give the BODIPY 4a (230 mg, 94\%); m.p. $235-237^{\circ} \mathrm{C} ;{ }^{1} \mathrm{H}$ NMR (400 MHz; $\left.\mathrm{CDCl}_{3}\right): \delta=6.09$ (s, $\left.2 \mathrm{H}\right), 2.52$ (s, $6 \mathrm{H}), 2.45 \mathrm{ppm}(\mathrm{s}, 6 \mathrm{H}) ;{ }^{13} \mathrm{C} \mathrm{NMR}\left(100 \mathrm{MHz} ; \mathrm{CDCl}_{3}\right): \delta=155.26,142.84,136.54,129.72$, 121.36, 16.68, $14.54 \mathrm{ppm}$; UV/Vis $\left(\mathrm{CH}_{2} \mathrm{Cl}_{2}\right): \lambda_{\max }(\varepsilon)=503 \mathrm{~nm}(61 \mathrm{700}) ; \mathrm{HRMS}(\mathrm{ESI}): \mathrm{m} / \mathrm{z}$ calcd for $\mathrm{C}_{13} \mathrm{H}_{15} \mathrm{ClF}_{2} \mathrm{~N}_{2}$ : 282.1016; found: 282.1010 .

BODIPY 4b: BODIPY $\mathbf{4 b}$ was prepared, using the same procedure as described above, from 5-chloro-dipyrrin hydrochloride $\mathbf{3 b}$ (325 mg, 96\%); m.p. 173-175 ${ }^{\circ} \mathrm{C} ;{ }^{1} \mathrm{H}$ NMR (400 $\left.\mathrm{MHz} ; \mathrm{CDCl}_{3}\right): \delta=2.50(\mathrm{~s}, 6 \mathrm{H}), 2.41(\mathrm{~m}, 10 \mathrm{H}), 1.05 \mathrm{ppm}(\mathrm{t}, J=7.6 \mathrm{~Hz}, 6 \mathrm{H}) ;{ }^{13} \mathrm{C}$ NMR $(100$ $\left.\mathrm{MHz} ; \mathrm{CDCl}_{3}\right): \delta=153.36,138.10,135.16,133.20,129.16,17.11,14.75,13.82,12.49 \mathrm{ppm}$; UV/Vis $\left(\mathrm{CH}_{2} \mathrm{Cl}_{2}\right): \lambda_{\max }(\varepsilon)=527 \mathrm{~nm}(31600)$; HRMS (ESI): $\mathrm{m} / z$ calcd for $\mathrm{C}_{17} \mathrm{H}_{22} \mathrm{BClFN}_{2}$ : $319.1549\left[M^{+}-\mathrm{F}\right]$; found: 319.1550 . 


\section{BODIPY 5a}

Method A: Dipyrrylketone 1a $(60 \mathrm{mg}, 0.27 \mathrm{mmol})$ was dissolved in dry $\mathrm{CHCl}_{3}(20 \mathrm{~mL})$ and triethyloxonium tetrafluoroborate $(105.1 \mathrm{mg}, 0.54 \mathrm{mmol})$ was added. The solution turned red with time and UV/Vis spectroscopy showed a sharp peak at $438 \mathrm{~nm}$. The mixture was stirred overnight and then washed with water, brine and finally dried over anhydrous $\mathrm{Na}_{2} \mathrm{SO}_{4}$. After evaporation, the residue was dissolved in $\mathrm{CHCl}_{3}(30 \mathrm{~mL})$ and DIEA (1.62 mmol, 6 equiv) was added and the solution was stirred for about $30 \mathrm{~min}$ before addition of $\mathrm{BF}_{3} \cdot \mathrm{OEt}_{2}$ ( $2.7 \mathrm{mmol}, 10$ equiv); the solution was then stirred overnight. UV/Vis spectroscopy showed a sharp peak at $487 \mathrm{~nm}$. Then, the mixture was washed with aq $\mathrm{NaHCO}_{3}$, brine and then dried over anhydrous $\mathrm{Na}_{2} \mathrm{SO}_{4}$. The residue was purified by silicagel column chromatography (eluted with $\mathrm{CH}_{2} \mathrm{Cl}_{2}$ /hexane) to give BODIPY $\mathbf{5 a}$ as an orange red solid (64 mg, 82\%).

Method B: BODIPY 4a (56.4 mg, $0.20 \mathrm{mmol})$ was dissolved in $\mathrm{MeOH}$ in an ice bath and $\mathrm{NaOEt}$ (20.4 mg, $0.3 \mathrm{mmol}$ ) was added. The mixture was stirred for $45 \mathrm{~min}$ and was monitored by TLC analysis and UV/Vis spectroscopy. The solvent was removed in vacuo and the residue was taken up in $\mathrm{CHCl}_{3}$ and washed with water, brine and then dried over anhydrous $\mathrm{Na}_{2} \mathrm{SO}_{4}$. The product was purified by chromatography (eluted with $\mathrm{CH}_{2} \mathrm{Cl}_{2} /$ hexane) to give an orange solid (26.8 mg, 46\%); m.p. $126-128{ }^{\circ} \mathrm{C} ;{ }^{1} \mathrm{H}$ NMR (400 MHz; $\mathrm{CDCl}_{3}$ ): $\delta=6.02(\mathrm{~s}, 2 \mathrm{H}), 4.12(\mathrm{q}, J=7.1 \mathrm{~Hz}, 2 \mathrm{H}), 2.51(\mathrm{~s}, 6 \mathrm{H}), 2.38(\mathrm{~s}, 6 \mathrm{H}), 1.53 \mathrm{ppm}(\mathrm{t}$, $J=7.1 \mathrm{~Hz}, 3 \mathrm{H}) ;{ }^{13} \mathrm{C} \mathrm{NMR}\left(100 \mathrm{MHz} ; \mathrm{CDCl}_{3}\right): \delta=159.12,154.13,139.13,127.94,119.57$, 74.14, 15.31, 14.45, $13.75 \mathrm{ppm}$; UV/Vis $\left(\mathrm{CH}_{2} \mathrm{Cl}_{2}\right): \lambda_{\max }(\varepsilon)=487 \mathrm{~nm}(58$ 900); HRMS (ESI): $m / z$ calcd for $\mathrm{C}_{15} \mathrm{H}_{19} \mathrm{BF}_{2} \mathrm{~N}_{2} \mathrm{O}: 292.1668$; found: 292.1654 .

BODIPY 5b: Method A: Yield: (66 mg, 71\%); Method B: Yield: (36.2 mg, 52\%); m.p. 135-137 ${ }^{\circ} \mathrm{C} ;{ }^{1} \mathrm{H}$ NMR $\left(400 \mathrm{MHz} ; \mathrm{CDCl}_{3}\right): \delta=4.09$ (q, $\left.J=7.1 \mathrm{~Hz}, 2 \mathrm{H}\right), 2.48(\mathrm{~s}, 6 \mathrm{H}), 2.48$ (q, $J=7.5 \mathrm{~Hz}, 4 \mathrm{H}), 2.32(\mathrm{~s}, 6 \mathrm{H}), 1.55(\mathrm{t}, J=7.1 \mathrm{~Hz}, 3 \mathrm{H}), 1.06 \mathrm{ppm}(\mathrm{t}, J=7.5 \mathrm{~Hz}, 6 \mathrm{H}) ;{ }^{13} \mathrm{C}$ NMR $\left(100 \mathrm{MHz} ; \mathrm{CDCl}_{3}\right): \delta=158.04,152.19,134.73,131.53,73.88,17.04,15.29,14.68,12.41$, $11.22 \mathrm{ppm}$; UV/Vis $\left(\mathrm{CH}_{2} \mathrm{Cl}_{2}\right): \lambda_{\max }(\varepsilon)=508 \mathrm{~nm}(27500)$; HRMS (ESI): $\mathrm{m} / z$ calcd for $\mathrm{C}_{19} \mathrm{H}_{27} \mathrm{BFN}_{2} \mathrm{O}\left(\mathrm{M}^{+}-\mathrm{F}\right): 329.2200$; found: 329.2167 .

Methyl 3,5-dimethylpyrrole-2-carboxylate 6-Dipyrromethene 3a (47.0 mg, 0.17 mmol) was dissolved in $\mathrm{CHCl}_{3}$ and $0.5 \mathrm{M} \mathrm{NaOMe}$ in $\mathrm{MeOH}(1.0 \mathrm{~mL}, 0.5 \mathrm{mmol})$ was added at room temperature; the mixture was stirred overnight and the reaction was monitored by TLC analysis and spectrophotometry. The solution was washed with water, brine and then dried over anhydrous $\mathrm{Na}_{2} \mathrm{SO}_{4}$. The solvent was removed and the product was purified by silica-gel column chromatography (eluted with $\mathrm{MeOH} / \mathrm{CH}_{2} \mathrm{Cl}_{2}$ ); Yield: $21 \mathrm{mg}$, 80.8\%; m.p. 93-95 ${ }^{\circ} \mathrm{C}$ (literature $\left.{ }^{[44]} 98-99^{\circ} \mathrm{C}\right) ;{ }^{1} \mathrm{H}$ NMR $\left(400 \mathrm{MHz} ; \mathrm{CDCl}_{3}\right): \delta=9.27$ (s, $\left.1 \mathrm{H}\right), 5.79$ (s, $1 \mathrm{H}), 3.83$ (s, 3H), 2.30 (s, 3H), $2.25 \mathrm{ppm}(\mathrm{s}, 3 \mathrm{H}) ;{ }^{13} \mathrm{C} \mathrm{NMR}\left(100 \mathrm{MHz} ; \mathrm{CDCl}_{3}\right): \delta=163.43$, 132.97, 129.14, 117.53, 111.34, 50.92, 12.96, $12.82 \mathrm{ppm}$; HRMS (ESI): $\mathrm{m} / \mathrm{z}$ calcd for $\mathrm{C}_{8} \mathrm{H}_{12} \mathrm{NO}_{2}: 154.0868\left[M+\mathrm{H}^{+}\right]$; found: 154.0870 (see the Supporting Information for X-ray structure).

Ethyl 3,5-dimethylpyrrole-2-carboxylate 7-This compound was prepared as described for pyrrole $\mathbf{6}$, except that sodium ethoxide was used as the base in ethanol. Yield: 
$19.0 \mathrm{mg}, 66.2 \%$; m.p. $118-119^{\circ} \mathrm{C}$ (literature $\left.{ }^{[45]} 125^{\circ} \mathrm{C}\right) ;{ }^{1} \mathrm{H} \mathrm{NMR}\left(400 \mathrm{MHz}, \mathrm{CDCl}_{3}\right)$ :

$\delta=8.68(\mathrm{~s}, 1 \mathrm{H}), 5.79(\mathrm{~s}, 1 \mathrm{H}), 4.31(\mathrm{q}, J=7.1 \mathrm{~Hz}, 2 \mathrm{H}), 2.30(\mathrm{~s}, 3 \mathrm{H}), 2.24(\mathrm{~s}, 3 \mathrm{H}), 1.34 \mathrm{ppm}(\mathrm{t}$, $J=7.1 \mathrm{~Hz}, 3 \mathrm{H}) ;{ }^{13} \mathrm{C}$ NMR $\left(100 \mathrm{MHz} ; \mathrm{CDCl}_{3}\right): \delta=161.69,132.28,129.02,117.78,111.35$, 59.68, 14.57, 13.07, $12.77 \mathrm{ppm}$; HRMS (ESI): $\mathrm{m} / z$ calcd for $\mathrm{C}_{9} \mathrm{H}_{14} \mathrm{NO}_{2}: 168.1019\left[M+\mathrm{H}^{+}\right]$; found: 168.1016 (see the Supporting Information for X-ray structure).

\section{BODIPY 11}

Method A: 5-Chloro-dipyrrin 3a (100 mg, $0.37 \mathrm{mmol})$ was dissolved in $\mathrm{CHCl}_{3}(40 \mathrm{~mL})$ and 1.0 M EtMgBr in THF $(1.30 \mathrm{~mL}, 1.30 \mathrm{mmol})$ was added dropwise at $0{ }^{\circ} \mathrm{C}$; the reaction was left stirring for $1 \mathrm{~h}$ at $0{ }^{\circ} \mathrm{C}$ and then for another $2 \mathrm{~h}$ at room temperature. Then, the solution was poured into ice water to destroy excess $\mathrm{EtMgBr}$, and extracted with $\mathrm{CHCl}_{3}$. The organic layers were combined and washed with water, brine and then dried over anhydrous $\mathrm{Na}_{2} \mathrm{SO}_{4}$. After evaporation, the residue (a mixture of compounds 9 and $\mathbf{1 0})$ in $\mathrm{CHCl}_{3}(30 \mathrm{~mL})$ and DIEA $(0.45 \mathrm{~mL}, 7$ equiv, $2.58 \mathrm{mmol})$ in an ice bath was treated with $\mathrm{BF}_{3} \cdot \mathrm{OEt}_{2}(0.53 \mathrm{~mL}$, 12.0 equiv, $4.3 \mathrm{mmol}$ ) and the mixture was stirred overnight. The solvent was removed and the residue was purified on a silica-gel column (eluted with $\mathrm{CH}_{2} \mathrm{Cl}_{2}$ /hexane) to give BODIPY 11. Yield: $20.1 \mathrm{mg}, 19.6 \%$.

Method B: ChloroBODIPY 4a (56.4 mg, $0.2 \mathrm{mmol})$ was dissolved in anhydrous THF and $1.0 \mathrm{M} \mathrm{EtMgBr}$ in THF $(0.5 \mathrm{~mL}, 0.5 \mathrm{mmol})$ was added dropwise to the solution at $-70^{\circ} \mathrm{C}$ with vigorous stirring. When the reaction was complete, according to TLC analysis and spectrophotometry, the solution was poured into ice water to destroy the excess Grignard reagent. Then the mixture was extracted three times with $\mathrm{CHCl}_{3}$, the organic phases were combined and washed with water, brine and then dried over anhydrous $\mathrm{Na}_{2} \mathrm{SO}_{4}$. The solvent was evaporated and the residue was purified by silicagel column chromatography (eluted with $\mathrm{CH}_{2} \mathrm{Cl}_{2} /$ hexane) to give the product as an orange-red solid (40 mg, 75\%); m.p. 214 $216^{\circ} \mathrm{C} ;{ }^{1} \mathrm{H}$ NMR $\left(400 \mathrm{MHz} ; \mathrm{CDCl}_{3}\right): \delta=6.05$ (s, 2H), 3.01 (q, J=7.5 Hz, 2H), $2.52(\mathrm{~s}, 6 \mathrm{H})$, 2.44 (s, 6H), $1.32 \mathrm{ppm}(\mathrm{t}, J=7.5 \mathrm{~Hz}, 3 \mathrm{H}) ;{ }^{13} \mathrm{C} \mathrm{NMR}\left(100 \mathrm{MHz} ; \mathrm{CDCl}_{3}\right): \delta=153.87,147.87$, 140.30, 131.20, 121.55, 21.29, 16.30, 15.45, $14.45 \mathrm{ppm}$; HRMS (ESI): $\mathrm{m} / \mathrm{z}$ calcd for $\mathrm{C}_{15} \mathrm{H}_{19} \mathrm{BF}_{2} \mathrm{~N}_{2}$ : 276.1718; found: 276.1713; UV/Vis $\left(\mathrm{CH}_{2} \mathrm{Cl}_{2}\right): \lambda_{\max }(\varepsilon) 499 \mathrm{~nm}$ (56 200). The meso-unsubstituted BODIPY was also eluted from the column $(6.0 \mathrm{mg}, 10 \%)$; m.p. $185-187^{\circ} \mathrm{C} ;{ }^{1} \mathrm{H}$ NMR $\left(400 \mathrm{MHz} ; \mathrm{CDCl}_{3}\right): \delta=7.04$ (s, 1H), 6.05 (s, 2H), $2.53(\mathrm{~s}, 6 \mathrm{H}), 2.25$ ppm (s, 6H); ${ }^{13} \mathrm{C}$ NMR (100 MHz; $\left.\mathrm{CDCl}_{3}\right): \delta=156.75,141.20,133.41,120.07,119.02$, 14.67, $11.28 \mathrm{ppm}$; UV/Vis $\left(\mathrm{CH}_{2} \mathrm{Cl}_{2}\right): \lambda_{\max }(\varepsilon)=507 \mathrm{~nm}(19600)$; HRMS (ESI): $\mathrm{m} / z$ calcd for $\mathrm{C}_{13} \mathrm{H}_{15} \mathrm{BF}_{2} \mathrm{~N}_{2}$ : 248.1405; found: 248.1404 .

BODIPY 12: $1.0 \mathrm{M}$ Ethyl magnesium bromide $(1.0 \mathrm{~mL}, 1.0 \mathrm{mmol})$ in THF was added to chloroBODIPY $4 \mathbf{a}(56.4 \mathrm{mg}, 0.2 \mathrm{mmol})$ in THF $(20 \mathrm{~mL})$ at room temperature and stirred for $1 \mathrm{~h}$; the reaction was quenched by addition of aq $\mathrm{NH}_{4} \mathrm{Cl}$ and then extracted with $\mathrm{CHCl}_{3}$. The organic extract was washed with water, brine and then dried over anhydrous $\mathrm{Na}_{2} \mathrm{SO}_{4}$. BODIPY 12 was isolated as the sole product by using silica-gel column chromatography (eluted with $\mathrm{CH}_{2} \mathrm{Cl}_{2}$ /hexane). Yield: $49 \mathrm{mg}$, $83 \%$; m.p. $135-137{ }^{\circ} \mathrm{C}$; ${ }^{1} \mathrm{H} \mathrm{NMR}(400 \mathrm{MHz}$; $\mathrm{CDCl}_{3}$ ): $\delta=6.08$ (s, 2H), 3.07 (q, J=7.5 Hz, 2H), 2.46 (s, 6H), 2.44 (s, 6H), 1.31 (t, J=7.5 Hz, $3 \mathrm{H}), 0.79 \mathrm{ppm}(\mathrm{m}, 4 \mathrm{H}), 0.30(\mathrm{~m}, 6 \mathrm{H}) ;{ }^{13} \mathrm{C}$ NMR $\left(100 \mathrm{MHz} ; \mathrm{CDCl}_{3}\right): \delta=150.08,135.52$, 131.77, 122.06, 21.34 16.97, 16.39, 15.93, 9.00, 1.02 ppm; ${ }^{11} \mathrm{~B}$ NMR (128 MHz; $\left.\mathrm{CDCl}_{3}\right)$ : 
$\delta=1.37 \mathrm{ppm}$; UV/Vis $\left(\mathrm{CH}_{2} \mathrm{Cl}_{2}\right): \lambda_{\max }(\varepsilon)=499 \mathrm{~nm}(15 \mathrm{800}) ; \mathrm{HRMS}(\mathrm{ESI}): \mathrm{m} / z$ calcd for $\mathrm{C}_{19} \mathrm{H}_{30} \mathrm{BN}_{2}$ : 296.2533; found: 296.2507.

BODIPY 13: 8-Chloro-BODIPY 4a (56.4 mg, $0.2 \mathrm{mmol})$ was dissolved in $\mathrm{MeOH}$ (30 mL) in an ice bath and $\mathrm{NaOMe}(16.5 \mathrm{mg}, 0.3 \mathrm{mmol})$ was added; the mixture was stirred for 45 min and the reaction was monitored by TLC analysis and spectrophotometry. The solvent was removed in vacuo and the residue was taken up in $\mathrm{CHCl}_{3}$ and washed with water, brine and then dried over anhydrous $\mathrm{Na}_{2} \mathrm{SO}_{4}$. The product was purified by silica-gel column chromatography (eluted with $\mathrm{CH}_{2} \mathrm{Cl}_{2}$ /hexane). The major fraction was the desired BODIPY product 13. Yield: $37.1 \mathrm{mg}, 67 \%$; m.p. $160-161{ }^{\circ} \mathrm{C} ;{ }^{1} \mathrm{H}$ NMR $\left(400 \mathrm{MHz} ; \mathrm{CDCl}_{3}\right.$ ): $\delta=6.03$ (s, 2H), 3.98 (s, 3H), 2.51 (s, 6H), $2.40 \mathrm{ppm}(\mathrm{s}, 6 \mathrm{H}) ;{ }^{13} \mathrm{C} \mathrm{NMR}\left(100 \mathrm{MHz} ; \mathrm{CDCl}_{3}\right): \delta=159.95$, $154.76,138.33,128.30,119.56,64.32,49.12,14.47,13.76 \mathrm{ppm}$; UV/Vis $\left(\mathrm{CH}_{2} \mathrm{Cl}_{2}\right): \lambda_{\max }$ $(\varepsilon)=487 \mathrm{~nm}$ (89 100); HRMS (ESI): $\mathrm{m} / z$ calcd for $\mathrm{C}_{14} \mathrm{H}_{18} \mathrm{BF}_{2} \mathrm{~N}_{2} \mathrm{O}: 278.1511$; found: 278.1504. The monomethoxyboron-substituted BODIPY was also separated as a minor fraction from the column (Yield: $12.0 \mathrm{mg}, 21 \%$ ); ${ }^{1} \mathrm{H} \mathrm{NMR}\left(400 \mathrm{MHz} ; \mathrm{CDCl}_{3}\right.$ ): $\delta=6.02$ (s, 2H), 3.97 (s, 3H), 2.89 (s, 3H), 2.51 (s, 6H), $2.37 \mathrm{ppm}(\mathrm{s}, 6 \mathrm{H}) ;{ }^{13} \mathrm{C} \mathrm{NMR}(100 \mathrm{MHz}$; $\left.\mathrm{CDCl}_{3}\right): \delta=159.95,154.76,138.33,128.30,119.56,64.24,49.12,14.47,13.76 \mathrm{ppm} ;{ }^{11} \mathrm{~B}$ NMR (128 MHz; $\mathrm{CDCl}_{3}$ ): $\delta=1.58 \mathrm{ppm}$; HRMS (ESI): $\mathrm{m} / z$ calcd for $\mathrm{C}_{14} \mathrm{H}_{17} \mathrm{BFN}_{2} \mathrm{O}$ : 259.1418 [ $\left.\mathrm{M}^{+}-\mathrm{OMe}\right]$; found: 259.1392. A small amount of the dimethoxyboron BODIPY 15 was also isolated from the column, but in insufficient quantity to fully characterize.

BODIPY 14: 8-Chloro-BODIPY 4a $(56.4 \mathrm{mg}, 0.2 \mathrm{mmol})$ was dissolved in THF (30 mL) in an ice bath and sodium phenoxide ( $34.8 \mathrm{mg}, 0.3 \mathrm{mmol}$ ) was added; the mixture was stirred for $2 \mathrm{~h}$ at room temperature and monitored by TLC analysis and spectrophotometry. The solvent was removed in vacuo and the residue was taken up in $\mathrm{CHCl}_{3}$ and washed with water, brine and then dried over anhydrous $\mathrm{Na}_{2} \mathrm{SO}_{4}$. The product was purified by silica-gel column chromatography (eluted with $\mathrm{CH}_{2} \mathrm{Cl}_{2} /$ hexane) to give an orange solid (55 $\mathrm{mg}, 81 \%$ ); m.p. $188-190{ }^{\circ} \mathrm{C} ;{ }^{1} \mathrm{H}$ NMR $\left(400 \mathrm{MHz} ; \mathrm{CDCl}_{3}\right)$ : $\delta=7.36-7.25(\mathrm{~m}, 2 \mathrm{H}), 7.08-7.06(\mathrm{~m}, 1 \mathrm{H})$, 7.01-6.99 (m, 2H), 5.99 (s, 2H), 2.55 (s, 6H), 2.04 ppm (s, 6H); ${ }^{13} \mathrm{C}$ NMR (100 MHz; $\left.\mathrm{CDCl}_{3}\right): \delta=157.52,155.78,151.59,140.42,130.08,127.62,122.84,119.99,114.70,14.60$, $14.14 \mathrm{ppm} ; \mathrm{UV} / \mathrm{Vis}\left(\mathrm{CH}_{2} \mathrm{Cl}_{2}\right): \lambda_{\max }(\varepsilon)=491 \mathrm{~nm}(51300)$; HRMS (ESI): $\mathrm{m} / z$ calcd for $\mathrm{C}_{19} \mathrm{H}_{20} \mathrm{BF}_{2} \mathrm{~N}_{2} \mathrm{O}: 340.1668$; found: 340.1662 .

BODIPY 15: 8-Chloro-BODIPY 4a (56.4 mg, $0.2 \mathrm{mmol})$ was dissolved in $\mathrm{MeOH}$ (30 mL) and $\mathrm{NaOMe}(54.0 \mathrm{mg}, 0.75 \mathrm{mmol}$ ) was added before the solution was heated at reflux temperature, under argon for $12 \mathrm{~h}$. The solvent was removed and the residue was taken up in $\mathrm{CHCl}_{3}$ and washed with water, brine and then dried over anhydrous $\mathrm{Na}_{2} \mathrm{SO}_{4}$. The product was separated by silica-gel chromatography (eluted with $\mathrm{MeOH} / \mathrm{CH}_{2} \mathrm{Cl}_{2}$ ). Yield: $38 \mathrm{mg}$, 65\%; m.p. 93-95 ${ }^{\circ} \mathrm{C} ;{ }^{1} \mathrm{H}$ NMR (400 MHz; $\mathrm{CDCl}_{3}$ ): $\delta=6.01$ (s, 2H), 3.97 (s, 3H), 2.86 (s, $6 \mathrm{H}), 2.48$ (s, 6H), $2.41 \mathrm{ppm}(\mathrm{s}, 6 \mathrm{H}) ;{ }^{13} \mathrm{C} \mathrm{NMR}\left(100 \mathrm{MHz} ; \mathrm{CDCl}_{3}\right): \delta=159.92,154.87$, 137.38, 129.02, 119.33, 64.13, 49.04, 14.41, $13.81 \mathrm{ppm} ;{ }^{11} \mathrm{~B} \mathrm{NMR}\left(128 \mathrm{MHz} ; \mathrm{CDCl}_{3}\right)$ : $\delta=2.39 \mathrm{ppm}$; UV/Vis $\left(\mathrm{CH}_{2} \mathrm{Cl}_{2}\right): \lambda_{\max }(\varepsilon)=487 \mathrm{~nm}$ (46 800); HRMS (ESI): $\mathrm{m} / z$ calcd for $\mathrm{C}_{16} \mathrm{H}_{23} \mathrm{BN}_{2} \mathrm{NaO}_{3}: 324.173\left[M^{+}+\mathrm{Na}\right]$; found: 324.1719 . The monomethoxyboron-substituted BODIPY (see above) was also separated as a minor fraction from the column (Yield: 9.3 $\mathrm{mg}, 16 \%)$. 
BODIPY 16: A solution of 8-chloro-BODIPY 4a (56.4 mg, $0.2 \mathrm{mmol}), 2$ mercaptobenzothiozole ( $40.0 \mathrm{mg}, 0.24 \mathrm{mmol}$ ), and $\mathrm{K}_{2} \mathrm{CO}_{3}(41.5 \mathrm{mg}, 0.3 \mathrm{mmol})$ in THF (30 $\mathrm{mL}$ ) was stirred at room temperature for $12 \mathrm{~h}$ or until the starting material was almost completely consumed. The solvent was removed in vacuo and the residue was taken up in $\mathrm{CHCl}_{3}$ and washed with water, brine and then dried over anhydrous $\mathrm{Na}_{2} \mathrm{SO}_{4}$. The product was purified by silica-gel column chromatography (eluted with $\mathrm{CH}_{2} \mathrm{Cl}_{2} /$ hexane). Yield: 46.1 mg, 56\%; m.p. $208-210^{\circ} \mathrm{C} .{ }^{1} \mathrm{H}$ NMR $\left(400 \mathrm{MHz} ; \mathrm{CDCl}_{3}\right): \delta=7.90(\mathrm{dt}, J=8.4,0.9 \mathrm{~Hz}, 1 \mathrm{H})$, $7.68(\mathrm{~m}, 1 \mathrm{H}), 7.44$ (ddd, $J=8.4,7.3,1.3 \mathrm{~Hz}, 1 \mathrm{H}), 7.31$ (ddd, $J=8.3,7.3,1.2 \mathrm{~Hz}, 1 \mathrm{H}), 6.10$ (s, 2H), 2.58 (s, 6H), $2.46 \mathrm{ppm}(\mathrm{s}, 6 \mathrm{H}) ;{ }^{13} \mathrm{C} \mathrm{NMR}\left(100 \mathrm{MHz} ; \mathrm{CDCl}_{3}\right): \delta=166.56,158.25$, $153.59,144.75,135.37,134.42,128.70,126.46,124.76,123.07,122.00,121.08,17.26$, $14.97 \mathrm{ppm}$; UV/Vis $\left(\mathrm{CH}_{2} \mathrm{Cl}_{2}\right): \lambda_{\max }(\varepsilon)=539 \mathrm{~nm}$ (49 000); HRMS (ESI): $\mathrm{m} / z$ calcd for $\mathrm{C}_{20} \mathrm{H}_{18} \mathrm{BFN}_{3} \mathrm{~S}$ : 394.1019 [M-F]; found: 394.1010.

BODIPY 17: A solution of 8-chloro-BODIPY 4a $(56.4 \mathrm{mg}, 0.2 \mathrm{mmol}), p$-carborane thiol (45.6 mg, $0.24 \mathrm{mmol}$ ), and $\mathrm{K}_{2} \mathrm{CO}_{3}(41.5 \mathrm{mg}, 3.0 \mathrm{mmol})$ in THF $(30 \mathrm{~mL})$ was stirred at room temperature for $12 \mathrm{~h}$ or until the starting material was consumed, The solvent was removed in vacuo and the residue was taken up in $\mathrm{CHCl}_{3}$ and washed with water, brine and then dried over anhydrous $\mathrm{Na}_{2} \mathrm{SO}_{4}$. The product was purified by column chromatography (eluted with $\mathrm{CH}_{2} \mathrm{Cl}_{2}$ /hexane) to give a red solid (80 mg, $92 \%$ ); m.p. $150-152^{\circ} \mathrm{C}$; ${ }^{1} \mathrm{H}$ NMR (400 MHz; $\left.\mathrm{CDCl}_{3}\right): \delta=6.06(\mathrm{~s}, 2 \mathrm{H}), 2.95(\mathrm{~s}, 2 \mathrm{H}), 2.51(\mathrm{~s}, 3 \mathrm{H}), 2.49$ (s, 3H), 2.17-1.68 ppm (m, $11 \mathrm{H}) ;{ }^{13} \mathrm{C} \mathrm{NMR}\left(100 \mathrm{MHz} ; \mathrm{CDCl}_{3}\right): \delta=156.14,143.51,136.84,134.23,122.50,59.04$, 46.04, 31.91, 16.91, $14.68 \mathrm{ppm}$; UV/Vis $\left(\mathrm{CH}_{2} \mathrm{Cl}_{2}\right): \lambda_{\max }(\varepsilon)=529 \mathrm{~nm}(17000) ;$ HRMS (ESI): $m / z$ calcd for $\mathrm{C}_{16} \mathrm{H}_{26} \mathrm{~B}_{11} \mathrm{~F}_{2} \mathrm{~N}_{2} \mathrm{~S}$ : 437.2808 ; found: 437.3033 .

\section{General procedure for Stille coupling reactions}

8-Chloro-BODIPY 4a (56.4 mg, $0.2 \mathrm{mmol})$, [Pd( $\left.\left.\mathrm{PPh}_{3}\right)_{4}\right](10.0 \mathrm{mg}, 5 \% \mathrm{mmol})$ and organotin reagent $(0.24-0.30 \mathrm{mmol})$ were added to a round-bottomed flask. The flask was flushed with argon and then anhydrous toluene was added, followed by injection of the Stille reagents. The mixture was refluxed for $5 \mathrm{~h}$, after which time the reaction was complete; the toluene was then removed and the residue was taken up in dichloromethane and washed with water, brine and then dried over anhydrous $\mathrm{Na}_{2} \mathrm{SO}_{4}$. The crude product was purified by silica-gel column chromatography (eluting with $\mathrm{CH}_{2} \mathrm{Cl}_{2} /$ hexane).

BODIPY 18-Yield: $60.1 \mathrm{mg}$, 93\%; m.p. $165-166^{\circ} \mathrm{C} ;{ }^{1} \mathrm{H}$ NMR (400 MHz; $\left.\mathrm{CDCl}_{3}\right)$ : $\delta=7.49-7.47(\mathrm{~m}, 3 \mathrm{H}), 7.29-7.27(\mathrm{~m}, 2 \mathrm{H}), 5.98(\mathrm{~s}, 2 \mathrm{H}), 2.56(\mathrm{~s}, 6 \mathrm{H}), 1.37 \mathrm{ppm}(\mathrm{s}, 6 \mathrm{H}) ;{ }^{13} \mathrm{C}$ NMR $\left(100 \mathrm{MHz} ; \mathrm{CDCl}_{3}\right): \delta=154.90,142.19,140.52,131.14,123.79,121.11,17.24,14.55$ ppm; UV/Vis $\left(\mathrm{CH}_{2} \mathrm{Cl}_{2}\right): \lambda_{\max }(\varepsilon)=501 \mathrm{~nm}(57500)$; HRMS (ESI): $\mathrm{m} / z$ calcd for $\mathrm{C}_{19} \mathrm{H}_{20} \mathrm{BF}_{2} \mathrm{~N}_{2}$ : 324.1718; found: 324.1717 .

BODIPY 19-Yield: $50.7 \mathrm{mg}$, 97\%; m.p. $245-247^{\circ} \mathrm{C} ;{ }^{1} \mathrm{H}$ NMR (400 MHz; $\left.\mathrm{CDCl}_{3}\right)$ : $\delta=6.05(\mathrm{~s}, 2 \mathrm{H}), 2.56(\mathrm{~s}, 6 \mathrm{H}), 2.51(\mathrm{~s}, 6 \mathrm{H}), 2.40 \mathrm{ppm}(\mathrm{s}, 3 \mathrm{H}) ;{ }^{13} \mathrm{C} \mathrm{NMR}\left(100 \mathrm{MHz} ; \mathrm{CDCl}_{3}\right)$ : $\delta=153.59,141.43,141.01,132.06,121.25,17.31,16.37,14.43 \mathrm{ppm} ; \mathrm{UV} / \mathrm{Vis}\left(\mathrm{CH}_{2} \mathrm{Cl}_{2}\right)$ : $\lambda_{\max }(\varepsilon)=487 \mathrm{~nm}(66000)$; HRMS (ESI): $\mathrm{m} / z$ calcd for $\mathrm{C}_{14} \mathrm{H}_{18} \mathrm{BF}_{2} \mathrm{~N}_{2}: 262.1562$; found: 262.1556. 
BODIPY 20-Yield: $53.1 \mathrm{mg}, 97 \%$; m.p. $228-230^{\circ} \mathrm{C}$; ${ }^{1} \mathrm{H}$ NMR (400 MHz; $\mathrm{CDCl}_{3}$ ): $\delta=6.74(\mathrm{dd}, J=14.3,9.1 \mathrm{~Hz}, 1 \mathrm{H}), 6.03(\mathrm{~s}, 2 \mathrm{H}), 5.69$ (dd, $J=12.0,2.2 \mathrm{~Hz}, 1 \mathrm{H}), 5.56(\mathrm{~d}$, $J=17.5,1.8 \mathrm{~Hz}, 1 \mathrm{H}), 2.53$ (s, 6H), $2.23 \mathrm{ppm}(\mathrm{s}, 6 \mathrm{H}) ;{ }^{13} \mathrm{C} \mathrm{NMR}\left(100 \mathrm{MHz} ; \mathrm{CDCl}_{3}\right)$ : $\delta=154.90,142.19,140.52,131.14,123.79,121.11,17.24,14.55 \mathrm{ppm}$; UV/Vis $\left(\mathrm{CH}_{2} \mathrm{Cl}_{2}\right)$ : $\lambda_{\max }(\varepsilon)=505 \mathrm{~nm}$ (46 000); HRMS (ESI): $\mathrm{m} / z$ calcd for $\mathrm{C}_{15} \mathrm{H}_{18} \mathrm{BF}_{2} \mathrm{~N}_{2}: 274.1562$; found: 274.1557.

BODIPY 21-Yield: $59.1 \mathrm{mg}, 93 \%$; m.p. $105-107{ }^{\circ} \mathrm{C} ;{ }^{1} \mathrm{H}$ NMR $\left(400 \mathrm{MHz} ; \mathrm{CDCl}_{3}\right)$ : $\delta=6.03$ (s, 2H), 4.46 (d, $J=2.9 \mathrm{~Hz}, 1 \mathrm{H}), 4.37$ (d, $J=2.8 \mathrm{~Hz}, 1 \mathrm{H}), 3.89$ (q, $J=7.0 \mathrm{~Hz}, 2 \mathrm{H}$ ), 2.52 (s, 6H), 2.23 (s, 6H), 1.39 ppm (t, J=7.0 Hz, 3H); ${ }^{13} \mathrm{C} \mathrm{NMR} \mathrm{(100} \mathrm{MHz;} \mathrm{CDCl}_{3}$ ): $\delta=155.97$, 153.56, 142.50, 134.98, 131.29, 88.11, 63.67, 14.65, $14.34 \mathrm{ppm}$; UV/Vis $\left(\mathrm{CH}_{2} \mathrm{Cl}_{2}\right): \lambda_{\max }$ $(\varepsilon)=513 \mathrm{~nm}(40700)$; HRMS (ESI): $\mathrm{m} / z$ calcd for $\mathrm{C}_{17} \mathrm{H}_{22} \mathrm{BF}_{2} \mathrm{~N}_{2} \mathrm{O}: 318.1824$; found: 318.1817 .

BODIPY 22-Yield: $16.8 \mathrm{mg}, 31 \%$; m.p. $>260^{\circ} \mathrm{C} ;{ }^{1} \mathrm{H}$ NMR (400 MHz; $\left.\mathrm{CDCl}_{3}\right): \delta=6.07$ (s, $2 \mathrm{H}), 3.92$ (s, $1 \mathrm{H}), 2.53$ (s, 6H), $2.45 \mathrm{ppm}(\mathrm{s}, 6 \mathrm{H}) ;{ }^{13} \mathrm{C} \mathrm{NMR}\left(100 \mathrm{MHz} ; \mathrm{CDCl}_{3}\right): \delta=155.07$, $142.61,133.28,121.06,118.92,94.42,79.19,15.47,14.63 \mathrm{ppm} ; \mathrm{UV} / \mathrm{Vis}\left(\mathrm{CH}_{2} \mathrm{Cl}_{2}\right): \lambda_{\max }$ $(\varepsilon)=544 \mathrm{~nm}$ (37 200); HRMS (ESI): $\mathrm{m} / z$ calcd for $\mathrm{C}_{15} \mathrm{H}_{16} \mathrm{BF}_{2} \mathrm{~N}_{2}$ : 272.1405; found: 272.1380 .

BODIPY 23-Yield: $21.7 \mathrm{mg}, 71.1 \%$ (starting with $25 \mathrm{mg}, 0.088 \mathrm{mmol}$ of 4a); m.p. $\approx 250^{\circ} \mathrm{C}$ "(decomposed)"; ${ }^{1} \mathrm{H}$ NMR $\left(400 \mathrm{MHz} ; \mathrm{CDCl}_{3}\right): \delta=6.06$ (s, $\left.2 \mathrm{H}\right), 2.52$ (s, $\left.6 \mathrm{H}\right)$, 2.46 (s, 6H), $0.29 \mathrm{ppm}(\mathrm{s}, 9 \mathrm{H}) ;{ }^{13} \mathrm{C} \mathrm{NMR}\left(100 \mathrm{MHz} ; \mathrm{CDCl}_{3}\right): \delta=154.40,142.23,133.05$, $120.78,120.05,115.01,110.44,15.54,14.61,0.68 \mathrm{ppm}$; UV/Vis $\left(\mathrm{CH}_{2} \mathrm{Cl}_{2}\right): \lambda_{\max }(\varepsilon)=545$ nm (42 500); HRMS (ESI): $m / z$ calcd for $\mathrm{C}_{18} \mathrm{H}_{23} \mathrm{BFN}_{2} \mathrm{Si}$ : 325.1708 [ $\left.M^{+}-\mathrm{F}\right]$; found: 325.1699 .

BODIPY 24—Yield: $62.1 \mathrm{mg}, 95 \%$; m.p. $179-181^{\circ} \mathrm{C} ;{ }^{1} \mathrm{H}$ NMR (400 MHz; $\mathrm{CDCl}_{3}$ ): $\delta=6.77(\mathrm{dd}, J=2.7,1.7 \mathrm{~Hz}, 1 \mathrm{H}), 6.21(\mathrm{dd}, J=3.6,2.7 \mathrm{~Hz}, 1 \mathrm{H}), 6.07(\mathrm{dd}, J=3.6,1.7 \mathrm{~Hz}, 1 \mathrm{H})$, $6.01(\mathrm{~s}, 2 \mathrm{H}), 3.40(\mathrm{~s}, 3 \mathrm{H}), 2.55(\mathrm{~s}, 6 \mathrm{H}), 1.50 \mathrm{ppm}(\mathrm{s}, 6 \mathrm{H}) ;{ }^{13} \mathrm{C} \mathrm{NMR}\left(100 \mathrm{MHz} ; \mathrm{CDCl}_{3}\right): \delta=$ 156.14, 143.34, 133.13, 131.73, 124.64, 122.47, 121.01, 109.34, 108.84, 33.84, 14.67, 12.68 ppm; UV/Vis $\left(\mathrm{CH}_{2} \mathrm{Cl}_{2}\right): \lambda_{\max }(\varepsilon)=513 \mathrm{~nm}(53 \mathrm{700})$; HRMS (ESI): $\mathrm{m} / z$ calcd for $\mathrm{C}_{18} \mathrm{H}_{21} \mathrm{BF}_{2} \mathrm{~N}_{2}: 327.1827$.

BODIPY 25-Yield: $69.8 \mathrm{mg}$, 99\%; m.p. $197-199^{\circ} \mathrm{C} ;{ }^{1} \mathrm{H}$ NMR (400 MHz; $\left.\mathrm{CDCl}_{3}\right)$ : $\delta=7.50(\mathrm{dd}, J=5.0,1.3 \mathrm{~Hz}, 1 \mathrm{H}), 7.13(\mathrm{dd}, J=5.1,3.5 \mathrm{~Hz}, 1 \mathrm{H}), 6.99(\mathrm{dd}, J=3.5,1.3 \mathrm{~Hz}, 1 \mathrm{H})$, 6.00 (s, 2H), 2.55 (s, 6H), $1.58 \mathrm{ppm}(\mathrm{s}, 6 \mathrm{H}) ;{ }^{13} \mathrm{C} \mathrm{NMR}\left(100 \mathrm{MHz} ; \mathrm{CDCl}_{3}\right): \delta=156.07$, 143.50, 134.64, 133.99, 132.41, 127.81, 127.61, 127.41, 121.50, 14.64, 13.55 ppm; UV/Vis $\left(\mathrm{CH}_{2} \mathrm{Cl}_{2}\right): \lambda_{\max }(\varepsilon)=514 \mathrm{~nm}(74100) ; \mathrm{HRMS}(\mathrm{ESI}): \mathrm{m} / z$ calcd for $\mathrm{C}_{17} \mathrm{H}_{17} \mathrm{BF}_{2} \mathrm{~N}_{2} \mathrm{NaS}$ : $352.1102\left[M^{+}+\mathrm{Na}\right]$; found: 352.1094 .

\section{Crystal data and refinement}

Diffraction data were collected at low temperature (90 or $100 \mathrm{~K})$ on either a Nonius KappaCCD diffractometer equipped with MoKa radiation $(\lambda=0.71073 \AA$ ) or a Bruker Kappa Apex-II DUO diffractometer equipped with $\mathrm{Mo}$ or $\mathrm{Cu}_{\mathrm{Ka}}$ radiation $(\lambda=1.54184 \AA$ ) . 
Refinement was by full-matrix least squares using SHELXL, with $\mathrm{H}$ atoms in idealized positions. Compound $\mathbf{4 b}$ has three independent molecules. Compound 19 lies on a mirror plane in the crystal, and its central Me group is disordered into two conformations. Disorder of the thiophene was present in $\mathbf{2 5}$, and the crystal of $\mathbf{1 7}$ was a non-merohedral twin.

Crystal data-For 4a: $\mathrm{C}_{13} \mathrm{H}_{14} \mathrm{BClF}_{2} \mathrm{~N}_{2}$; monoclinic; $P 2{ }_{1} / c ; a=8.6711(17), b=12.274(3)$, $c=11.850(2) \AA ; \beta=97.570(8)^{\circ} ; Z=4 ; T=100 \mathrm{~K} ; R=0.040 .4 \mathbf{b}: \mathrm{C}_{17} \mathrm{H}_{22} \mathrm{BClF}_{2} \mathrm{~N}_{2}$; triclinic; $P 1$; $a=8.6228(5), b=12.4360(7), c=12.4491(6) \AA ; a=93.806(3), \beta=107.076(3), \gamma=100.514(3)^{\circ}$; $Z=3 ; T=100 \mathrm{~K} ; R=0.052 .5 \mathrm{a}: \mathrm{C}_{15} \mathrm{H}_{19} \mathrm{BF}_{2} \mathrm{~N}_{2} \mathrm{O}$; monoclinic; $P 21 / n ; a=10.5564(9)$, $b=11.8910(10), c=12.4508(14) \AA ; \beta=112.982(4)^{\circ} ; Z=4 ; T=90 \mathrm{~K} ; R=0.036 .5 \mathbf{b}$ : $\mathrm{C}_{19} \mathrm{H}_{27} \mathrm{BF}_{2} \mathrm{~N}_{2} \mathrm{O}$; monoclinic; $C c ; a=13.9165(9), b=17.1597(10), c=8.4065(5) \AA ; \beta=$ 114.970(5) $; Z=4 ; T=100 \mathrm{~K} ; R=0.034$. 16: $\mathrm{C}_{20} \mathrm{H}_{18} \mathrm{BF}_{2} \mathrm{~N}_{3} \mathrm{~S}_{2} ;$ monoclinic; $P 2_{1} / c$; $a=11.7044(17), b=14.871(2), c=10.9035(17) \AA ; \beta=93.116(10)^{\circ} ; Z=4 ; T=100 \mathrm{~K} ; R=0.038$. 17: $\mathrm{C}_{16} \mathrm{H}_{27} \mathrm{~B}_{11} \mathrm{~F}_{2} \mathrm{~N}_{2} \mathrm{~S}$; monoclinic; $P 2{ }_{1} / c ; a=13.8364(9), b=13.3718(11), c=12.0936(12) \AA$; $\beta=93.295(6)^{\circ} ; Z=4 ; T=100 \mathrm{~K} ; R=0.136 .18: \mathrm{C}_{19} \mathrm{H}_{19} \mathrm{BF}_{2} \mathrm{~N}_{2} ;$ monoclinic; $P 2_{1} / n$, $a=11.812(3), b=7.0804(17), c=19.362(5) \AA ; \beta=99.545(14)^{\circ} ; Z=4 ; T=100 \mathrm{~K}, R=0.049$. 19: $\mathrm{C}_{14} \mathrm{H}_{17} \mathrm{BF}_{2} \mathrm{~N}_{2}$; orthorhombic; Pnma; $a=11.3154(16), b=7.0396(10), c=16.013(2) \AA ; Z=4$; $T=100 \mathrm{~K} ; R=0.039$. 20: $\mathrm{C}_{15} \mathrm{H}_{17} \mathrm{BF}_{2} \mathrm{~N}_{2} ;$ monoclinic; $P 2{ }_{1} / n ; a=10.0991(5), b=11.7547(6)$, $c=11.9808(7) \AA ̊=107.886(3)^{\circ} ; Z=4 ; T=100 \mathrm{~K} ; R=0.046 .24: \mathrm{C}_{18} \mathrm{H}_{20} \mathrm{BF}_{2} \mathrm{~N}_{3}$; monoclinic; $P 2_{1} ; a=7.2814(11), b=12.4570(19), c=9.2579(15) \AA ; \beta=100.858(8)^{\circ} ; Z=2 ; T=100 \mathrm{~K} ; R=$ 0.042. 25: $\mathrm{C}_{17} \mathrm{H}_{17} \mathrm{BF}_{2} \mathrm{~N}_{2} \mathrm{~S}$; monoclinic; $P 2_{1} / c ; a=6.6072(10), b=18.543(2), c=12.7436(15)$ $\AA ; \beta=92.804(6)^{\circ} ; Z=4 ; T=90 \mathrm{~K} ; R=0.034$. CCDC-959961-959970, 959972 contains the supplementary crystallographic data for this paper. These data can be obtained free of charge from The Cambridge Crystallographic Data Centre via www.ccdc.cam.ac.uk/ data_request/cif.

\section{Steady-state absorption and fluorescence spectroscopy}

The absorption measurements were carried out on an Agilent 8453 spectrophotometer and the steady-state fluorescence spectroscopic studies were performed in dichloromethane on a PTI Quanta-Master4/2006SE spectrofluorimeter. The slit width was $3 \mathrm{~nm}$ for both the excitation and emission. For the fluorescence quantum yield measurements, dilute solutions with absorbance between $0.04-0.06$ at the excitation wavelength were used. The fluorescence quantum yields of BODIPYs were obtained by comparing the area under the corrected emission spectrum of the test sample with that of rhodamine $6 \mathrm{G}$ in ethanol. All spectra were recorded at room temperature by using non-degassed samples, spectroscopic grade solvents and a $10 \mathrm{~mm}$ quartz cuvette.

\section{Supplementary Material}

Refer to Web version on PubMed Central for supplementary material.

\section{Acknowledgments}

This work was supported by the US National Institutes of Health, grant CA132861. 


\section{References}

1. Smith KM. Quart Rev Chem Soc. 1971; 25:31-85.

2. Ballantine JA, Jackson AH, Kenner GW, McGillivray G. Tetrahedron. 1966; 22:241-259.

3. Goud TV, Tutar A, Biellmann JF. Tetrahedron. 2006; 62:5084-5091.

4. Smith, KM.; Vicente, MGH. Science of Synthesis. Vol. 17.8. Georg Thieme Verlag; Stuttgart: 2004. p. 1081-1334.

5. Clezy PS, Liepa AJ, Smythe GA. Aust J Chem. 1970; 23:603-608.

6. Jackson AH, Kenner GW, McGillivray G, Smith KM. J Chem Soc C. 1968:294-302.

7. Treibs A, Kreuzer FH. Justus Liebigs Ann Chem. 1968; 718:208-223.

8. Falk H, Hofer O, Lehner H. Monatsh Chem. 1974; 105:169-178.

9. Loudet A, Burgess K. Chem Rev. 2007; 107:4891-4932. [PubMed: 17924696]

10. Ulrich G, Ziessel R, Harriman A. Angew Chem. 2008; 120:1202-1219.Angew Chem Int Ed. 2008; 47:1184-1201.

11. Karolin J, Johansson LBA, Strandberg L, Ny T. J Am Chem Soc. 1994; 116:7801-7806.

12. Tan K, Jaquinod L, Paolesse R, Nardis S, Di Natale C, Di Carlo A, Prodi L, Montalti M, Zaccheroni N, Smith KM. Tetrahedron. 2004; 60:1099-1106.

13. Lee CH, Lindsey JS. Tetrahedron. 1994; 50:11427-11440.

14. Ulrich G, Ziessel R. J Org Chem. 2004; 69:2070-2083. [PubMed: 15058955]

15. Wang D, Fan J, Gao X, Wang B, Sun S, Peng X. J Org Chem. 2009; 74:7675-7683. [PubMed: 19772337]

16. Wu L, Burgess K. Chem Commun. 2008:4933-4935.

17. Leen V, Yuan P, Wang L, Boens N, Dehaen W. Org Lett. 2012; 14:6150-6153. [PubMed: 23214969]

18. Osorio-Martínez CA, Urías-Benavides A, Gómez-Durán CFA, Bañuelos J, Esnal I, López Arbeloa I, Peña-Cabrera E. J Org Chem. 2012; 77:5434-5438. [PubMed: 22607162]

19. Plater MJ, Aiken S, Bourhill G. Tetrahedron. 2002; 58:2405-2413.

20. Fischer H, Orth H. Justus Liebigs Ann Chem. 1933; 502:237-264.

21. Diem MJ, Burow DF, Fry JL. J Org Chem. 1977; 42:1801-1802.

22. Smith KM, Miura M, Tabba HD. J Org Chem. 1983; 48:4779-4781.

23. Li L, Nguyen B, Burgess K. Bioorg Med Chem Lett. 2008; 18:3112-3116. [PubMed: 18037291]

24. Kee HL, Kirmaier C, Yu L, Thamyongkit P, Youngblood WJ, Calder ME, Ramos L, Noll BC, Bocian DF, Scheidt WR, Birge RR, Lindsey JS, Holten D. J Phys Chem B. 2005; 109:2043320433. [PubMed: 16853644]

25. Goze C, Ulrich G, Mallon LJ, Allen BD, Harriman A, Ziessel R. J Am Chem Soc. 2006; 128:10231-10239. [PubMed: 16881653]

26. Gabe Y, Ueno T, Urano Y, Kojima H, Nagano T. Anal Bioanal Chem. 2006; 386:621-626. [PubMed: 16924384]

27. Bhupathiraju NVSDK, Vicente MGH. Bioorg Med Chem. 2013; 21:485-495. [PubMed: 23219853]

28. Miyaura N, Suzuki A. Chem Rev. 1995; 95:2457-2483.

29. Stille JK, Lau KSY. J Am Chem Soc. 1976; 98:5841-5849.

30. Heck RF. J Am Chem Soc. 1968; 90:5518-5526.

31. Sonogashira K, Tohda Y, Hagihara N. Tetrahedron Lett. 1975; 16:4467-4470.

32. Rohand T, Qin W, Boens N, Dehaen W. Eur J Org Chem. 2006:4658-4663.

33. Thivierge C, Bandichhor R, Burgess K. Org Lett. 2007; 9:2135-2138. [PubMed: 17455941]

34. a) Qin W, Rohand T, Dehaen W, Clifford JN, Driesen K, Beljonne D, VanAverbeke B, Van der Auweraer M, Boens N. J Phys Chem A. 2007; 111:8588-8597. [PubMed: 17696329] b) Leen V, Braeken E, Luckermans K, Jackers C, Van derAuweraer M, Boens N, Dehaen W. Chem Commun. 2009:4515-4517. 
35. Jiao L, Yu C, Uppal T, Liu M, Li Y, Zhou Y, Hao E, Hu X, Vicente MGH. Org Biomol Chem. 2010; 8:2517-2519. [PubMed: 20390194]

36. Li F, Yang SI, Ciringh Y, Seth J, Martin CH, Singh DL, Kim D, Birge RR, Bocian DF, Holten D, Lindsey JS. J Am Chem Soc. 1998; 120:10001-10017.

37. Ortiz MJ, Agarrabeitia AR, Duran-Sampedro G, Prieto JB, Lopez TA, Massad WA, Montejano HA, Garcia NA, Arbeloa IL. Tetrahedron. 2012; 68:1153-1162.

38. a) Miyaura N, Yamada K, Suzuki A. Tetrahedron Lett. 1979; 20:3437-3440.b) Miyaura N, Yano T, Suzuki A. Tetrahedron Lett. 1980; 21:2865-2868.c) Miyaura N, Suzuki A. Chem Commun. 1979:866-867.d) Miyaura N, Yanagi T, Suzuki A. Synth Commun. 1981; 11:513-519.

39. a) Stille JK. Angew Chem. 1986; 98:504-519.Angew Chem Int Ed. 1986; 25:508-524.b) Milstein D, Stille JK. J Am Chem Soc. 1978; 100:3636-3638.

40. Gräf K, Korzdorfer T, Kummel S, Thelakkat M. New J Chem. 2013; 37:1417-1426.

41. Gabe Y, Urano Y, Kikuchi K, Kojima H, Nagano T. J Am Soc Chem. 2004; 126:3357-3367.

42. Sun J, Zhong F, Yi X, Zhao J. Inorg Chem. 2013; 52:6299-6310. [PubMed: 23327589]

43. Gibbs JH, Robins LT, Zhou Z, Bobadova-Parvanova P, Cottam M, McCandless GT, Fronczek FR, Vicente MGH. Bioorg Med Chem. 2013; 21:5770-5781. [PubMed: 23928070]

44. Boiadjiev SE, Lightner DA. Tetrahedron: Asymmetry. 2002; 13:1721-1732.

45. Fischer H, Orth H. Justus Liebigs Ann Chem. 1931; 489:62-86.

46. Fischer, H.; Orth, H. Die Chemie des Pyrrols. Akademische Verlag; Leipzig: 1934. p. 238 

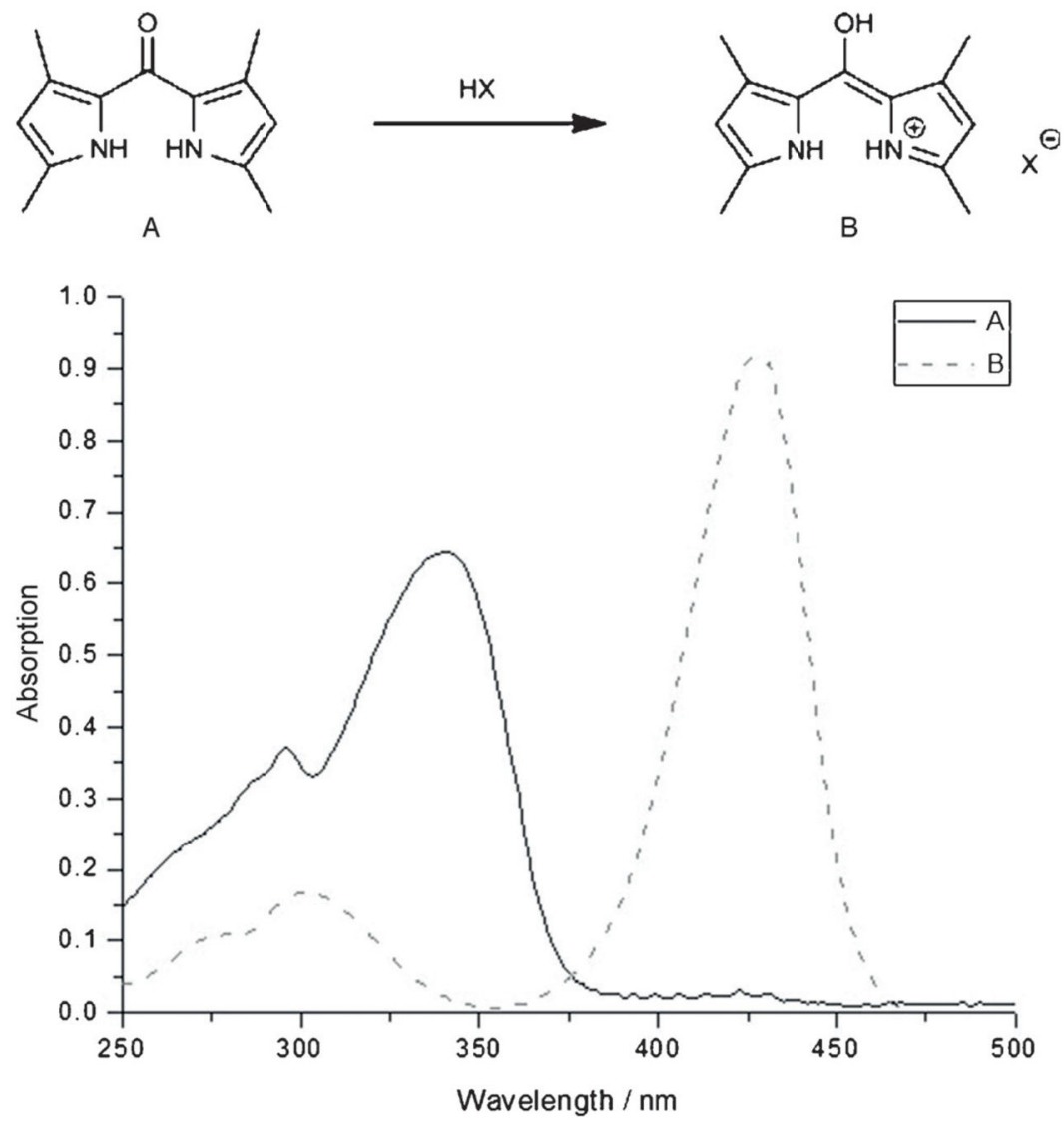

Figure 1.

Optical spectra, in dichloromethane, of dipyrrylketone (A) and dipyrrinium salt (B) after treatment with $\mathrm{HCl}(\mathrm{g})$. 

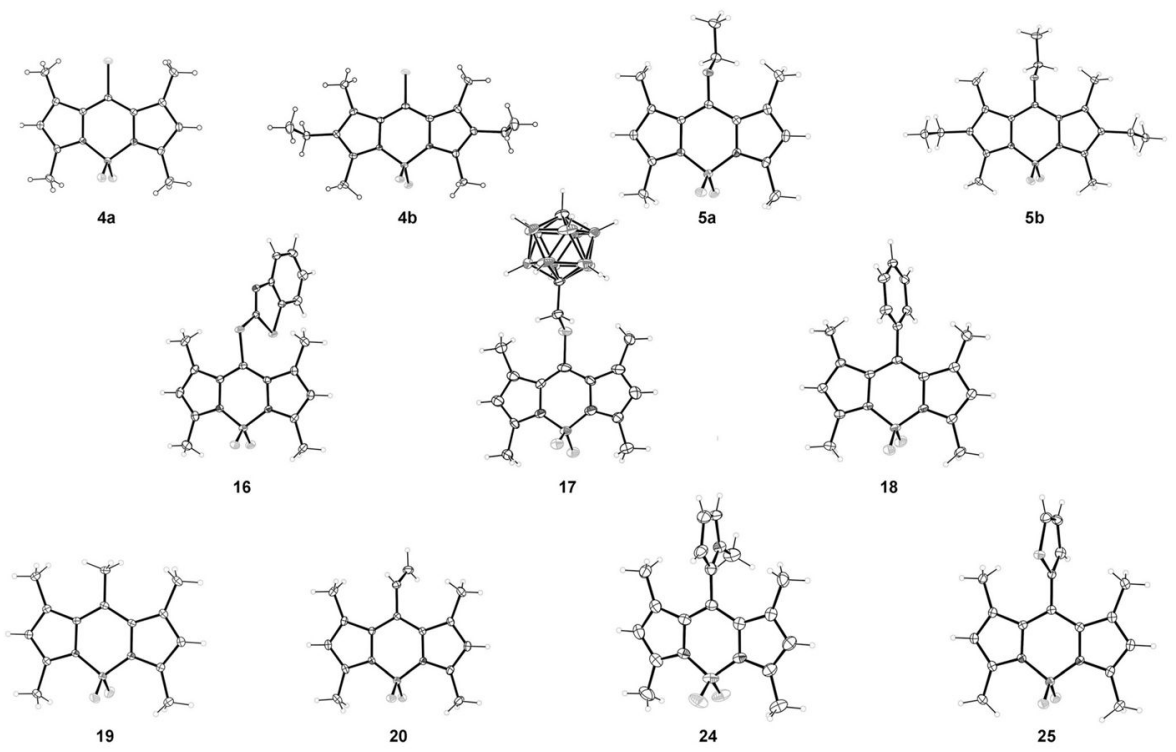

Figure 2.

Molecular structures of some BODIPY products. 


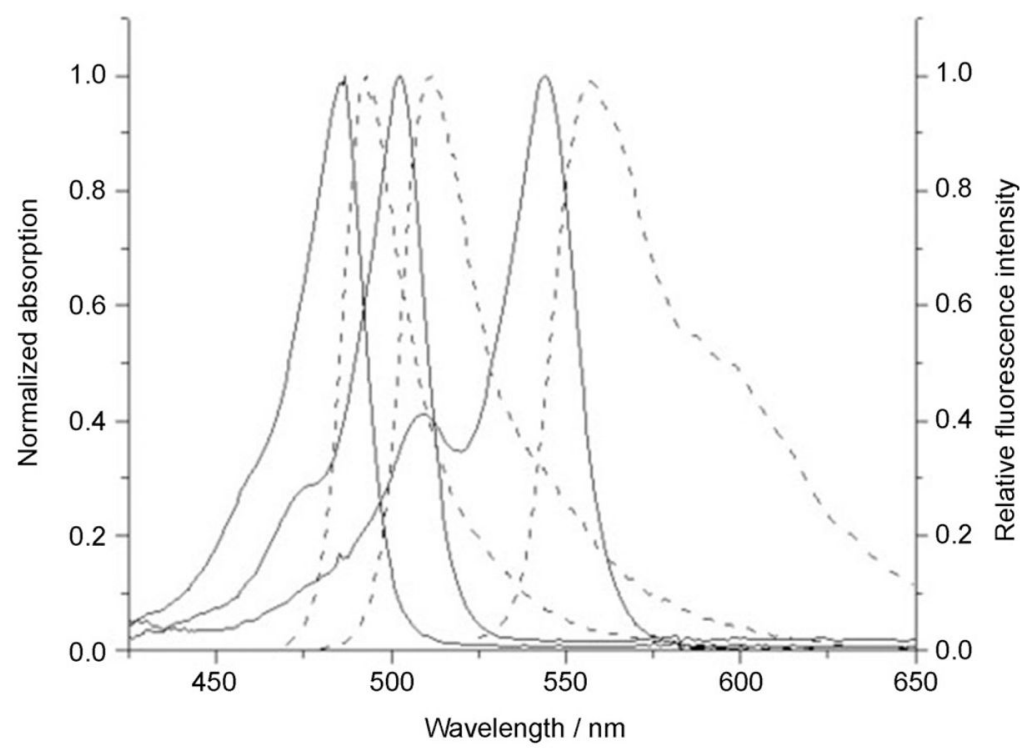

Figure 3.

Normalized UV/Vis absorption (solid line) and fluorescence emission spectra (dashed line) of selected BODIPYs 5a, 4a, and 22 (left to right), in dichloromethane. 
<smiles>[R]c1c(C)c[nH]c1C</smiles>

2a,b

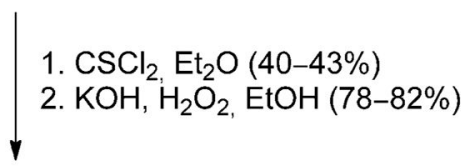<smiles>[R]c1c(C)[nH]c(C(=O)c2[nH]c(C)c(C)c2C)c1C</smiles>

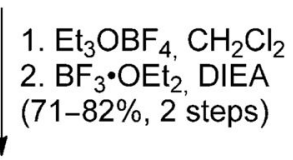<smiles></smiles>

$5 a, b$

a: $R=H$

b: $R=E t$

$\underset{(90-93 \%)}{\stackrel{\mathrm{COCl}_{2}, \mathrm{CH}_{2} \mathrm{Cl}_{2}}{\longrightarrow}}$

EtONa, EtOH<smiles>c1ccc2ccccc2c1</smiles><smiles>COC(=O)c1[nH]c(C)cc1C</smiles>

6

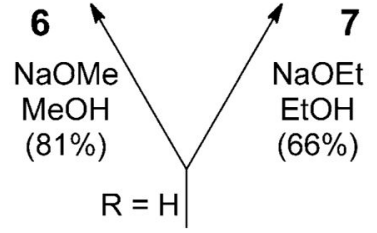<smiles></smiles>

$3 a, b$

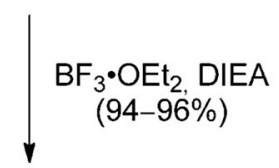<smiles></smiles>

$4 a, b$

Scheme 1.

Synthesis of 5-chloro-dipyrrins $\mathbf{3}$ and BODIPYs $\mathbf{4}$ and $\mathbf{5}$. 
<smiles></smiles>
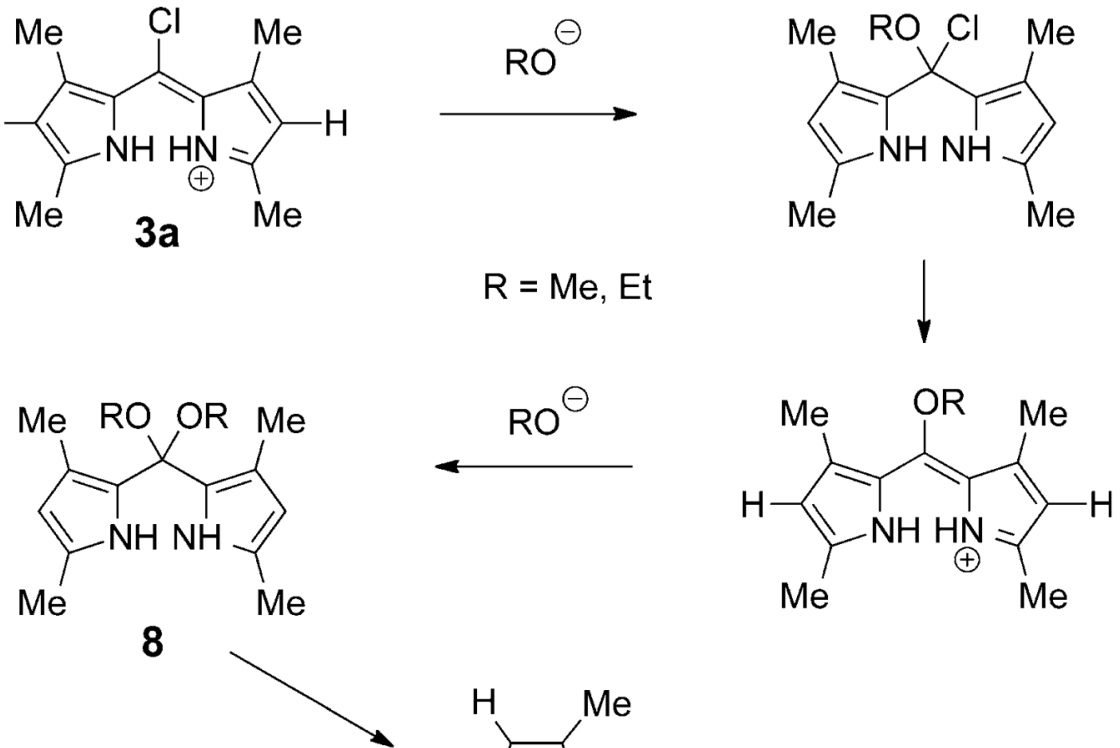<smiles>[R]OC(=O)c1ccc(C)[nH]1</smiles>

$6 \mathrm{R}=\mathrm{Me}$

$7 \mathrm{R}=\mathrm{Et}$

Scheme 2.

Proposed mechanism for the conversion of $\mathbf{3 a}$ into $\mathbf{6}$ and $\mathbf{7}$. 
3a
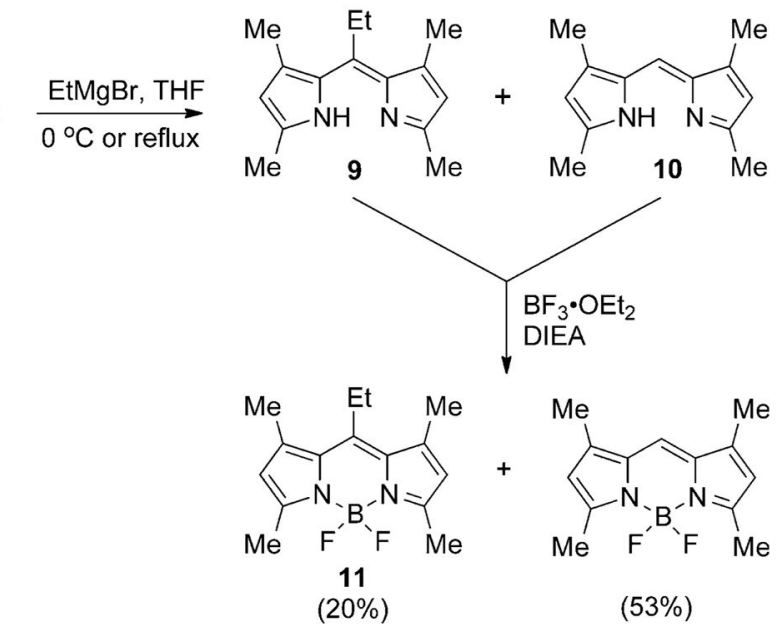

4a $\underset{-78^{\circ} \mathrm{C}}{\stackrel{\text { EtMgBr, THF }}{\longrightarrow}}$
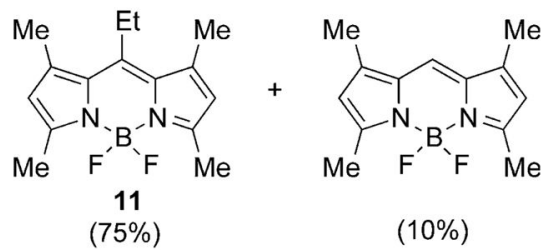

4a $\underset{0 \text { to } 25^{\circ} \mathrm{C}}{\stackrel{\mathrm{E} M g B r}{\mathrm{~T}}}$

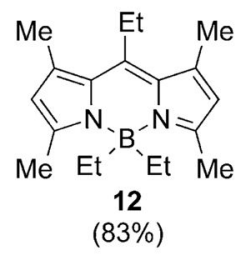

Scheme 3.

Reactions of chlorinated 3a and $\mathbf{4 a}$ with Grignard reagents. 

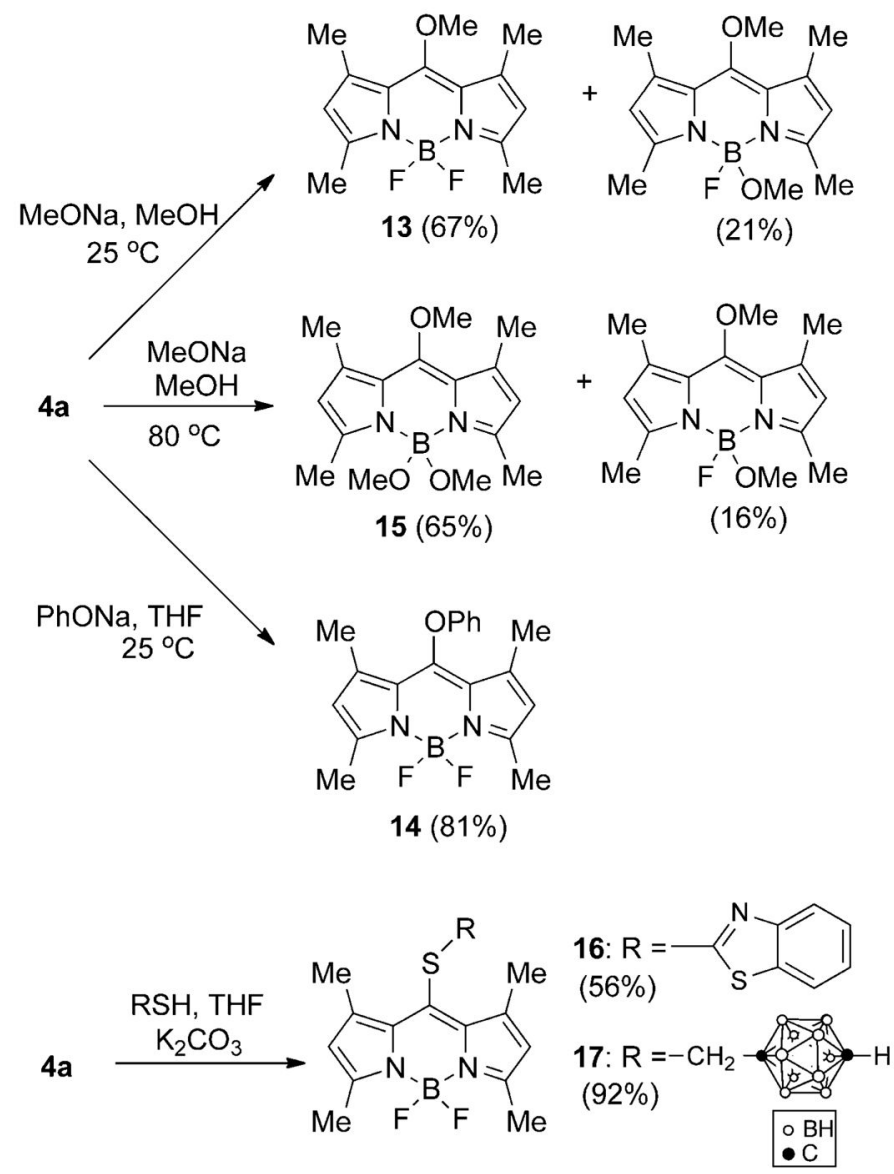

Scheme 4.

Nucleophilic substitutions/eliminations of BODIPY $\mathbf{4 a .}$ 


\section{Table 1}

Stille coupling reactions of 8-chloro-BODIPY $\mathbf{4 a .}$

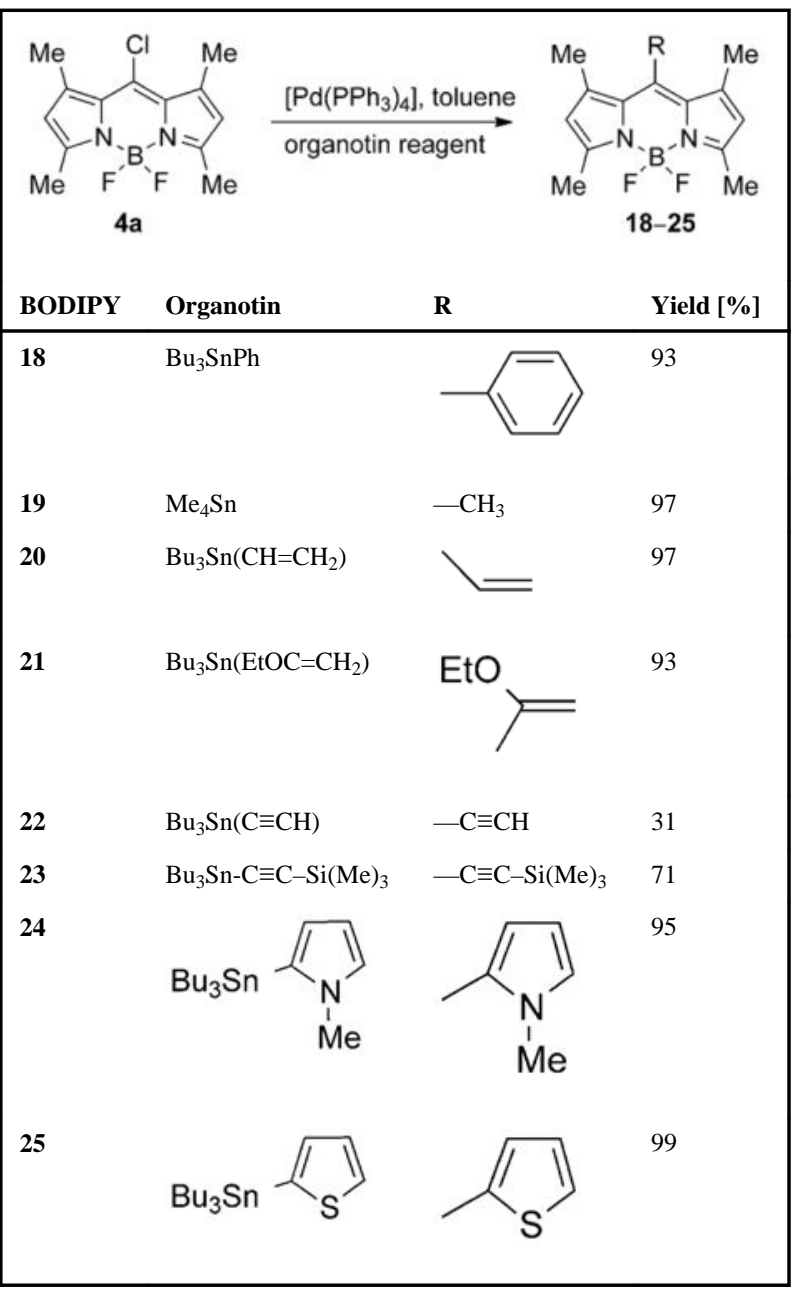




\section{Table 2}

Spectral properties of BODIPYs in dichloromethane solution at room temperature. The fluorescence quantum yields $\left(\lambda_{\text {exc }}=490 \mathrm{~nm}\right)$ were calculated by using, rhodamine $6 \mathrm{G}(0.80$ in ethanol $)$ as the reference.

\begin{tabular}{|lllll|}
\hline BODIPY & Absorbance $\lambda_{\text {max }}[\mathbf{n m}]$ & Emission $\boldsymbol{\lambda}_{\text {max }}[\mathbf{n m}]$ & $\boldsymbol{\Phi}_{\mathrm{f}}$ & $\mathbf{L o g} \boldsymbol{\varepsilon}\left[\mathbf{M}^{\mathbf{- 1}} \mathbf{c m}^{-1}\right]$ \\
\hline $\mathbf{4 a}$ & 503 & 512 & 0.51 & 4.79 \\
$\mathbf{4 b}$ & 527 & 542 & 0.33 & 4.50 \\
$\mathbf{5 a}$ & 487 & 493 & 0.99 & 4.77 \\
$\mathbf{5 b}$ & 508 & 518 & 0.67 & 4.44 \\
$\mathbf{1 1}$ & 499 & 505 & 0.83 & 4.75 \\
$\mathbf{1 2}$ & 499 & 507 & 0.32 & 4.20 \\
$\mathbf{1 3}$ & 487 & 493 & 0.57 & 4.95 \\
$\mathbf{1 4}$ & 491 & 499 & 0.99 & 4.71 \\
$\mathbf{1 5}$ & 487 & 496 & 1.00 & 4.67 \\
$\mathbf{1 6}$ & 539 & 553 & 0.04 & 4.69 \\
$\mathbf{1 7}$ & 529 & 542 & 0.09 & 4.23 \\
$\mathbf{1 8}$ & 501 & 511 & 0.62 & 4.76 \\
$\mathbf{1 9}$ & 497 & 508 & 0.77 & 4.82 \\
$\mathbf{2 0}$ & 505 & 511 & 0.00 & 4.67 \\
$\mathbf{2 1}$ & 513 & 522 & 0.14 & 4.61 \\
$\mathbf{2 2}$ & 544 & 556 & 0.29 & 4.57 \\
$\mathbf{2 3}$ & 545 & 556 & 0.13 & 4.63 \\
$\mathbf{2 4}$ & 513 & 521 & 0.10 & 4.73 \\
$\mathbf{2 5}$ & 514 & 521 & 0.05 & 4.87 \\
\hline
\end{tabular}

